\title{
For our world without sound. The opportunistic debitage in the Italian context: a methodological evaluation of the lithic assemblages of Pirro Nord, Cà Belvedere di Montepoggiolo, Ciota Ciara cave and Riparo Tagliente.
}

Mark Carpentieri ( $\square$ mark.carpentieri@gmail.com )

Universita' degli Studi di FERRARA https://orcid.org/0000-0003-4611-3089

Marta Arzarello

University of Ferrara: Universita degli Studi di Ferrara

Original Paper

Keywords: Lithic technology, Palaeolithic, Lower Pleistocene, Middle Pleistocene, Core technology

Posted Date: January 29th, 2021

DOI: https://doi.org/10.21203/rs.3.rs-176361/v1

License: (c) (i) This work is licensed under a Creative Commons Attribution 4.0 International License.

Read Full License 


\section{Abstract}

The opportunistic debitage, originally adapted from Forestier's S.S.D.A. definition, is characterized by a strong adaptability to local raw material morphology and its physical characteristics and it is oriented towards flake production. Its most ancient evidence is related to the first European peopling by Homo sp. during Lower Pleistocene starting from 1.6 Ma and gradually increasing around $1 \mathrm{Ma}$. In these sites a great heterogeneity of the reduction sequences and raw materials employed is highlighted, bringing to the identification of multiple technical behaviours. However, the scientific community does not always agree on associating the concepts of opportunism and method to describe these lithic complexes. The same methodological issues remain for the Middle Pleistocene where, simultaneously to an increase of the archaeological evidence and the persistence of the opportunistic debitage, the first bifacial complexes are attested. Further implications concerning the increasing complexity highlighted in core technology management are now at the centre of an important debate regarding the genesis of more specialized method (Levallois and Discoid) especially during MIS 12 and MIS 9. We suggest that the opportunistic debitage could be the starting point for this process, carrying within itself a great methodological and cultural potential.

\section{Introduction}

The opportunistic debitage refers to a flaking method adapted from Forestier's S.S.D.A. definition (1993) and developed in following works (Arzarello, 2003) from which the term opportunism has been originally defined and used for the first time. The opportunistic debitage has been initially described as "a method oriented to raw materials' massive exploitation without implying either a core's, or any surface, preparation. The striking platforms and knapping surfaces are created as far as the flaking activity is carried on. [...] The opportunistic debitage include an infinite range of variants always coming from the same common operative scheme" (traduced by Arzarello, 2003). The term opportunism was not picked with a negative meaning but in its original definition: "a behaviour in which someone adapts his actions to each context in order to gain from them the most advantage". This method shows a strong adaptability to local raw material morphology and its physical characteristics and it is oriented towards morphologically non-standardized flake production mainly achieved through short reduction sequences. The subordination to morphological criteria comes from a common predetermined mental scheme producing highly flexible and variable operative knapping schemes (unipolar, orthogonal, bipolar, and centripetal). These are constantly influenced by, and adjusted to, raw material volume as far as the flaking activity is carried on. The aim is the production of functional flakes deriving from a mental scheme easily replicable through the technical gesture. In this sense, the opportunistic debitage may be compared to the "Type C" one recently introduced by Eric Boëda (2013) with which shares the concept of subordination and adaptability to natural morphological criteria alongside the choice of natural suitable volumes for the start of flake production without any surfaces' preparation. The variability of the operative schemes used is always depending on and according to the natural morphologies available and to the cores' volume. In any case a surfaces' hierarchization (Levallois likewise; Boëda, 1994) or a 
subordination of the morphologies to specific technical criteria (such as in the Discoid and Quina method; Boëda, 1993; Bourguignon, 1997) is implied in the opportunistic debitage.

In the end, a contextualization has to be made regarding the branched/ramified productions (Bourguignon et al., 2004; Romagnoli et al., 2018; Mathias and Bourguignon, 2020; Mathias et al., 2020) and their role within the opportunistic debitage. Since they are considered highly dependent on the flaking method used for the main production (Bourguignon et al., 2004) and stand as a specific behavioural aspect of the human groups related to techno-economic issues (Mathias and Bourguignon, 2020) they may represent one of the several technical responses or adaptation through which a flaking method (the opportunistic one in this case) is achieved (Romagnoli et al., 2018).

The most ancient evidence of the opportunistic debitage are related to the first European peopling by Homo sp. during Lower Pleistocene starting from 1.6 Ma and gradually increasing around $1 \mathrm{Ma}$ (Despriée et al., 2010; 2018; Moncel, 2010; Ollé et al., 2013; Arzarello et al., 2016; Cheheb et al., 2019). In all these sites the lithic industry was obtained exploiting local raw material of different qualities (such as flint, limestone, sandstone, quartzite, and basalt) and morphologies (nodules, cobbles, pebbles). The reduction sequences attested, are mainly short and finalized to non-standardized flake production presenting at least one cutting edge achieved through multiple types of debitage (unipolar, orthogonal, bipolar, and centripetal), arbitrarily chosen depending on (or according to) the raw material's morphology and quality. Tools (usually denticulate and scrapers) are rarely attested (Despriée et al., 2010; Arzarello et al., 2016) and unretouched flakes are predominant. The direct percussion by hard hammer is the most commonly used technique, but the bipolar-on-anvil one is also recognized (de Lombera-Hermida et al., 2016). Since a great heterogeneity of the reduction sequences and raw materials employed is highlighted, the scientific community does not always agree on associating the concepts of opportunism (Arzarello, 2003) and method (Boëda, 1994) in order to describe the lithic complexes belonging to these sites. This brought to the identification of multiple technical behaviours, still without considering the presence of a possible common methodological substratum for these chronological phases which has only recently started to be considered and regarded as "opportunistic"(Agam et al., 2015; Peretto et al., 2016; Santagata et al., 2017; Vaquero and Romagnoli, 2018; Moncel et al., 2019; 2020a; 2020b).

During Middle Pleistocene, simultaneously along with an increase of archaeological evidence, a persistence of the opportunistic debitage can be attested throughout Europe. These assemblages are often associated to the first bifacial complexes (Preece and Parfitt, 2012; Barsky et al., 2013; Moncel et al., 2013; 2014; 2018; García-Medrano et al., 2015; Bourguignon et al., 2016; Martínez and Garcia Garriga, 2016; Santagata, 2016) or to small-medium flake ones (Parfitt et al., 2008; Despriée et al., 2010; Preece and Parfitt, 2012; Ollé et al., 2013; Gallotti and Peretto, 2015; Aureli et al., 2016; Rocca et al., 2016; Grimaldi et al., 2020), although terminological and methodological issues remain. The reduction sequences always comprehend strong flexibility and versatility, translating in a constant adaptation to the raw material's morphology and optimization of flake production. Further implications concerning the increasing complexity highlighted in core technology management for this period (especially regarding the length of the reduction sequences and surfaces' centripetal conception) are now at the centre of an 
important debate regarding the genesis of more predetermined method (i.e. Levallois and Discoid; Ollé et al., 2013; Moncel et al., 2014; 2016; 2020b; Rossoni-Notter et al., 2016). We suggest that the opportunistic debitage could be the starting point for this process, carrying within itself a great methodological and cultural potential.

Therefore, the first evidence of Levallois production (Prepared Core Technology, Moncel et al., 2020b) and its earliest diffusion during MIS 12 and MIS 9 (Moncel et al., 2016; Pereira et al., 2016; Rocca, 2016) determined a shift in the flakes complex's methodological analysis at the expense of the opportunistic debitage from this chronological phase onwards. Because of this, the contextualization of the opportunistic method within the cultural traditions of middle and upper Palaeolithic resulted to be nearly absent, few cases being excluded (Arzarello, 2003; Daffara, 2017; Santagata et al., 2017).

\section{Materials And Methods}

The Italian peninsula provides important archaeological evidence to contextualize the origin and the evolution of the opportunistic debitage during the Lower, Middle and Upper Pleistocene. For this reason, a selection of four sites (Pirro Nord, Cà Belvedere di Montepoggiolo, Ciota Ciara Cave and Riparo Tagliente; Fig. 1) from different chronological and environmental contexts was made to better underline this phenomenon through the technological analysis of the lithic assemblages.

The site of Pirro Nord (Foggia, Apulia, Italy) is situated in an active limestone quarry at the north-western margin of the Gargano promontory. It belongs to a karstic complex developed at the top of the Mesozoic limestone formation which is part of the "Apricena horst" (Pavia et al., 2012). In the sedimentary fillings of the Pirro 13 fissure (P13) lithic evidences were found alongside with Late Villafranchian vertebrate fossils of the Pirro Nord Faunal Unit (Gliozzi et al., 1997). The origin of the deposit is the result of several massive processes (such as debris-flow) which gradually filled the fissure from the top in a chaotic way, determining the transportation of artifacts and faunal remains (Giusti and Arzarello, 2016). The age of the site, estimated using biochronological data, falls between 1.3 and 1.6 Ma (López-García et al., 2015; Cheheb et al., 2019).

Cà Belvedere di Montepoggiolo is in North-east Italy near the town of Forlì. The geological succession of the area originated from the Plio-Pleistocenic marine deposits "argille-grigio-blu" (grey-blue clay) later covered by the "sabbie gialle" (yellow sands) and successively eroded by marine regression (Ricci Lucchi et al., 1982). The yellow sands are absent within the site and a pebble beach in a fluvial sand matrix was instead found, containing lithic assemblage in primary position (Peretto et al., 1998). The chronological range of the context has been set to $0.85 \mathrm{Ma}$ (shortly after the cooling of MIS22), correlating the latest paleomagnetic analysis with the biochronological data from the surrounding area since no faunal remains were found (Muttoni et al., 2011).

Ciota Ciara cave is located on the west slope of Monte Fenera's karst (899 m a. s. I.) at the entrance of the Sesia valley (Vercelli, Piedmont, Italy). It is a still active karstic cave whose archaeological interest has been the object of systematic excavations during the 60s, the 90 s and again from 2009 onwards 
(Fedele, 1966; Busa et al., 2005; Daffara et al., 2019). During the last investigations an important sequence at the entrance of the cave was unearthed and four main stratigraphical units were found, each one attesting a phase of human occupation (Angelucci et al., 2019). The archaeological record is very rich and includes faunal remains, lithic industry and anthropical evidences, (hearths and human remains; Arzarello et al., 2014). According to the chronological data so far gathered the human frequentation of the Ciota Ciara cave can be placed during the second half of the Middle Pleistocene (Berto et al., 2016; Vietti, 2016; Cavicchi, 2018).

Riparo Tagliente is a rock shelter situated on the west slope of Valpantena, one of the main valley bottoms of Monti Lessini (Verona, Veneto, Italy). Systematically investigated since 1967, a complex stratigraphy was unearthed attesting two distinct phases of human occupation: the lower one referred to MIS 4 - 3 with Mousterian and Aurignacian assemblages and the upper one dated to the Late Glacial with Late Epigravettian evidence. For both sequences a rich faunal record alongside human remains was brought to light (Fontana et al., 2002; Thun Hohenstein and Peretto, 2005; Arnaud et al., 2016). The age of the Mousterian sequence (the one studied in this paper) is estimated to be between 60 and 40 ka based on sedimentological analysis correlated with the faunal assemblages (Bartolomei et al., 1982).

The technological analysis was performed with the intention of reconstructing the knapping sequences and core reduction strategies of exclusively opportunistic assemblages. The aim was to identify the objectives of production, the operative schemes applied to obtain such products and, at the same time, to evaluate how those aspects were influenced by morphology. In order to do so technical criteria are required (Inizan et al., 1995; Boëda, 2013).

For the flakes, several attributes were considered. The knapping technique was identified through the analysis of the stigmata present on the butt and on the ventral face (impact point, ripples, hackles). The scars together with the presence/position of cortex were analysed for defining the knapping method and the different reduction sequences employed. The incidence of debordant and plunging flakes and their morphology were used to identify any possible "wanted product" together with the presence and position of the cutting edge (Van Gijn, 1989). Moreover, for each core a diacritical scheme was realized to recognize and interpret the final steps of core reduction. The dimensional analyses were performed on complete pieces. The technical dimensions of the items were measured according to the minimal rectangle or "box method" (Laplace, 1977). No size-categories were created, thus, a distinction on the basis of flakes' length was not required.

For all sites, a sample of lithic artifacts were considered with the aim of being, at the same time, the most characteristic (concerning raw material exploited and products) but also unintentionally selected regarding the opportunistic debitage (Tables $1-7$ ). In order to do so, cores, flakes (length $\geq 10 \mathrm{~mm}$ ) and tools coming from the richest levels concerning the opportunistic method were analysed and studied. Overall, the technical behaviours identified through the analysis of cores were divided into (I) unifacial and (II) multifacial, depending on the number of knapping surfaces exploited, (III) cores on flake and (IV) split fractures cores. The terms unipolar, centripetal, orthogonal, and bipolar, applied to cores' 
descriptions, indicate how each knapping surface was knapped according to scar removals' direction (Inizan et al., 1995). The supplementary data for the archaeological collection are available at this link: https://zenodo.org/record/4228014\#.X6E7T2hKhPY. 
Table 1

Sites, number of pieces and raw materials of the lithic assemblages analysed. In the case of Pirro Nord the whole stratigraphic sequence has been considered since is the result of a gravitative accumulation rather than a proper archaeological stratification due to distinct human occupations.

\begin{tabular}{|c|c|c|c|c|c|}
\hline Sites and levels & Total pieces & $\begin{array}{l}\text { Studied } \\
\text { pieces }\end{array}$ & Cores & Flakes & $\begin{array}{l}\text { Raw } \\
\text { material }\end{array}$ \\
\hline Pirro Nord & 340 & 108 & 19 & 89 & Flint \\
\hline $\begin{array}{l}\text { Cà Belvedere di } \\
\text { Montepoggiolo }\end{array}$ & 1319 (76 refitting) & $\begin{array}{l}83(23 \\
\text { refitting) }\end{array}$ & 14 & 69 & Flint \\
\hline Level 101 & & & 1 & 7 & \\
\hline Level 102 & & & 2 & 15 & \\
\hline Level 103 & & & 6 & 25 & \\
\hline Level 104 & & & 2 & 10 & \\
\hline Level 105 & & & 1 & 4 & \\
\hline Level 107 & & & 1 & 2 & \\
\hline Level 108 & & & - & 2 & \\
\hline Level 109 & & & 1 & - & \\
\hline Level 111 & & & - & 3 & \\
\hline Level 113 & & & - & 1 & \\
\hline Ciota Ciara cave & $\begin{array}{l}7046(5017 \\
\text { Quartz) }\end{array}$ & 112 & 8 & 104 & Quartz \\
\hline Level 14 & $\begin{array}{l}3983 \text { (3119 } \\
\text { Quartz) }\end{array}$ & & 8 & 104 & \\
\hline Riparo Tagliente & 36.812 & 112 & 11 & 101 & Flint \\
\hline Level 39 & 31 & & - & 7 & \\
\hline Level 41 & 30 & & - & 2 & \\
\hline Level 42 & 1397 & & 7 & 36 & \\
\hline Level 42 alfa & 380 & & - & 14 & \\
\hline Level 44 & 672 & & - & 12 & \\
\hline Level 45 & 160 & & - & 7 & \\
\hline Level 48 & 87 & & 1 & 3 & \\
\hline Level 49 & 187 & & 1 & 13 & \\
\hline Level 50 & 861 & & 1 & 1 & \\
\hline
\end{tabular}




\begin{tabular}{|lllccc|}
\hline Sites and levels & Total pieces & $\begin{array}{l}\text { Studied } \\
\text { pieces }\end{array}$ & Cores & Flakes & $\begin{array}{l}\text { Raw } \\
\text { material }\end{array}$ \\
\hline Level 51 & 356 & & - & 5 & \\
\hline Level 52 & 409 & & 1 & 1 & \\
\hline
\end{tabular}

An experimental collection for each site was obtained from the most abundant raw material in each context (Table 3). Pirro Nord and Cà Belvedere di Montepoggiolo were conceived together since the raw material morphology exploited in each one is very similar (i.e., small pebbles). Since the experimentation focused exclusively on the opportunistic debitage, its purposes revolved around two main aspects to evaluate its stability and versatility as a method: a) the volumetric evolution of each blocks from its initial morphology to its gradual modifications as the knapping activity was carried on and b) the identification of the main strategies and aspects influencing any operative schemes. To accomplish these tasks, the creation of the knapping-event concept, similar to the one of algorithm defined by Forestier (1993), was necessary (Fig. 2). The knapping event can be defined as "the choice of one striking platform and its related knapping surface from which the core will be knapped. The switch or the change of one, or both surfaces previously involved determines the end of that knapping event eventually allowing a new one to begin with". Each new striking platform was marked with consecutive numbers while the knapping surface with consecutive letters. The striking platform was always written before the knapping surface so that in case the chosen striking platform was formerly a knapping surface (or vice versa), the letters and the numbers were switched rather than using new ones. Once the core was discarded, an operative scheme was obtained by indicating the sequence of each knapping-event in chronological order (Fig. 2).

Moreover, before the starting of each experimental sequence, specific knapping goals were established to verify if they could have led to different choices regarding core management or if they required specific knapping patterns (Table 2). The choice of these goals was set according to the initial morphology and volume of the blocks, always considering the original archaeological context. Besides, to keep track of this process, any time that a knapping-event's switch was performed, or the core was discarded, the causes were written down based on knapper's indication (Table 2). The aim was to highlight and quantify the main factors affecting the flaking process by comparing each block's operative scheme with the resulting outcomes. Being able to follow the flaking's realization process all along, the following questions were addressed. Which are the main aspects influencing the volumetric evolution of the blocks? Are they identifiable? How much does the morphology affect the objectives of productions? Is there a concrete subordination to raw material morphology? And if so, is there any pattern distinguishable in the knapping activity? 
Table 2

Knapping goals of the experimental protocol.

\section{Experimental Protocol}

\section{Objectives of production
a) maximized flake-production

b) flake-production achieved through a single technical behaviour (i.e., centripetal)

c) flake production with predetermined functional and/or dimensional criteria (i.e., flake presenting a cutting edge of at least $40 \mathrm{~mm}$ )

Knappingevent change

1) absence of knapping criteria

2) choice of a new striking platform and/or knapping surfaces on arbitrary base (such as "better convexities available")

3) raw material quality

4) dimensional issues

5) impossibility to achieve the objective of production

6) core management (such as technical flakes)

7) knapping errors and/or accidents

The study of the experimental collection took place using the same technical criteria applied for the technological analysis of the archaeological material focusing on the direction of scars, incidence of debordant and plunging flakes and flake functionality (number and position of cutting edges; Van Gijn, 1989). The supplementary data for the experimental collection are available at this link: https://zenodo.org/record/4228014\#.X6E7T2hKhPY.

In the end, it is highlighted once again how the experimental knapping activity was applied as a constant analogy to get as close as possible (aware of being far from the absolute certainty) to the identification of a predominant operative scheme (i.e., method) by its application through several technical behaviour.

Table 3

Raw materials, number of blocks collected, and flakes obtained during the experimentation.

\begin{tabular}{|lllll|}
\hline Site & $\begin{array}{l}\mathbf{N}^{\circ} \text { of blocks } \\
\text { collected }\end{array}$ & $\begin{array}{l}\mathbf{N}^{\circ} \text { of flakes } \\
\text { obtained }\end{array}$ & $\begin{array}{l}\text { Raw } \\
\text { material }\end{array}$ & $\begin{array}{l}\text { Weight } \\
\mathbf{( k g )}\end{array}$ \\
\hline $\begin{array}{l}\text { Pirro Nord/Cà Belvedere di } \\
\text { Montepoggiolo }\end{array}$ & 10 & 302 & Flint & 2.960 \\
$\begin{array}{l}\text { Ciota Ciara cave } \\
\text { Riparo Tagliente }\end{array}$ & 10 & 204 & Quartz & 4.220 \\
\hline
\end{tabular}




\section{The Opportunistic Debitage Of Pirro Nord \& Cà Belvedere Di Montepoggiolo}

The raw materials employed in the above-mentioned sites, were locally selected from secondary deposits. The morphology and volume differed within each context, deeply affecting the reduction sequences. In Pirro Nord, small and medium sized pebbles $(\sim 30-80 \mathrm{~mm})$, mostly round and oval, were exploited and collected within the range of the site, in riverbeds or slope deposits. The recognized flint types, coming from the Gargano Cretaceous succession, are of good quality. In Montepoggiolo the procurement strategies recall the Pirro Nord ones, both in a qualitative and morphological way. Here, pebbles and cobbles are slightly longer and oval in shape ( 30-100 mm).

Each opportunistic assemblage was oriented towards non-standardized flake production presenting at least one cutting edge sometime opposed to a backed margin (cortical or flat) (Fig. 6, 7). The technical behaviours applied in each site are deeply related to the locally available morphologies, resulting in different knapping strategies. The presence of natural convexities on the selected blocks is one of the most relevant and more frequently attested features. This allows the production of functional flakes without implying a decortication phase or core preparation.

\subsection{Production}

In Pirro Nord and Cà Belvedere di Montepoggiolo the use of similar morphologies provided an identical technological response, repetitive and deeply assimilated into the method. In both sites the production was oriented towards roughly quadrangular flakes, which sometimes could be elongated depending on the initial morphology and volume of the core, especially for Montepoggiolo (Fig. 5, 6, 7). The flakes were obtained through unipolar, bipolar, and centripetal flaking (Fig. 11; Table 4). The dimensional data available for Pirro Nord, both from the archaeological and the experimental collection, highlights how the cobbles were originally mainly spherical, rarely larger than $60 \mathrm{~mm}$ (Fig. 5). Concerning Montepoggiolo, mostly large oval pebbles were knapped resulting in longer flakes (Fig. 5). All in all, two main reduction strategies were identified: a unidirectional-multifacial flake-production applied on larger volumes and a centripetal exploitation of the surfaces on smaller and more rounded cobbles. Given the original dimensions of the raw material and since the adaption to morphology was constant through the whole knapping process, the reduction sequences were short and arbitrarily applied on the same core (Table 4). 
Table 4

Typology of cores analysed in the archaeological (A.) and experimental (E.) record.

\begin{tabular}{|c|c|c|c|c|c|c|c|}
\hline \multirow[t]{2}{*}{ Types of core } & \multicolumn{2}{|c|}{$\begin{array}{l}\text { Pirro } \\
\text { Nord }\end{array}$} & \multirow{2}{*}{ 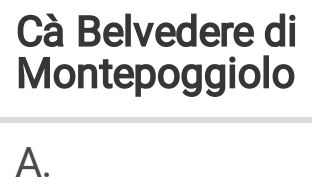 } & \multicolumn{2}{|c|}{$\begin{array}{l}\text { Ciota Ciara } \\
\text { cave }\end{array}$} & \multicolumn{2}{|c|}{$\begin{array}{l}\text { Riparo } \\
\text { Tagliente }\end{array}$} \\
\hline & A. & E. & & A. & E. & A. & E. \\
\hline \multicolumn{8}{|l|}{ Unifacial cores } \\
\hline Unipolar & 5 & 2 & 5 & 3 & 5 & 1 & \\
\hline Centripetal & 1 & 2 & 2 & & & 1 & 1 \\
\hline Bipolar & & 1 & & & & & \\
\hline Orthogonal & 2 & 2 & 1 & & & & \\
\hline \multicolumn{8}{|l|}{ Multifacial cores } \\
\hline Unipolar & 3 & 4 & 3 & 3 & 8 & 3 & 7 \\
\hline Unipolar-Bipolar & & & & & 2 & 1 & \\
\hline $\begin{array}{l}\text { Unipolar- } \\
\text { Orthogonal }\end{array}$ & 1 & 1 & 1 & 2 & & 2 & 2 \\
\hline Centripetal & 1 & & & & & & \\
\hline $\begin{array}{l}\text { Centripetal- } \\
\text { Unipolar }\end{array}$ & & 1 & 1 & & & 2 & \\
\hline Orthogonal & & & 1 & & & 1 & \\
\hline Bipolar & 2 & & & & & & \\
\hline Split fracture cores & 1 & & & & & & \\
\hline Cores on flake & 3 & & & & & & \\
\hline Total & 19 & 13 & 14 & 8 & 15 & 11 & 10 \\
\hline
\end{tabular}


Table 5

Pirro Nord 13. Analysis of the experimental cores. $\mathrm{N}^{\circ} \mathrm{S}$. P. indicates the final number of striking platforms on the abandoned cores. $\mathrm{N}^{\circ} \mathrm{K}$. S. indicates the final number of knapping surfaces on the abandoned

cores.

\begin{tabular}{|c|c|c|c|c|c|c|}
\hline Site & $\begin{array}{l}\text { Core } \\
\text { ID }\end{array}$ & $\begin{array}{l}\text { Knapping-events } \\
\text { sequence }\end{array}$ & Type of core & $\begin{array}{l}N^{\circ} \mathbf{S} . \\
\text { P. }\end{array}$ & $\begin{array}{l}\mathbf{N}^{\circ} \mathrm{K} . \\
\mathrm{S} .\end{array}$ & $\begin{array}{l}\mathrm{N}^{\circ} \\
\text { Flakes }\end{array}$ \\
\hline \multirow[t]{13}{*}{$\begin{array}{l}\text { Pirro } \\
\text { Nord }\end{array}$} & $\mathrm{n} 1$ & $1 a-a b-b c-2 c-c d-d c$ & $\begin{array}{l}\text { Multifacial (Centripetal - } \\
\text { Unipolar) }\end{array}$ & 6 & 5 & 31 \\
\hline & n2 & $1 a-2 a-3 a-a b$ & Multifacial (Unipolar) & 2 & 2 & 34 \\
\hline & n3 & $1 a-a b-b c-c b$ & Unifacial (Unipolar) & 1 & 1 & 42 \\
\hline & $\mathrm{n} 4 \mathrm{a}$ & 1a-a1 & Unifacial (Orthogonal) & 2 & 2 & 20 \\
\hline & $\mathrm{n} 4 \mathrm{~b}$ & 1a-a1 & Unifacial (Centripetal) & 2 & 2 & 36 \\
\hline & $\mathrm{n} 5 \mathrm{a}$ & $1 \mathrm{a}$ & Unifacial (Centripetal) & 1 & 1 & 11 \\
\hline & $n 5 b$ & $1 \mathrm{a}$ & Unifacial (Unipolar) & 1 & 1 & 14 \\
\hline & n6 & 1a-a1-1b-b1 & $\begin{array}{l}\text { Multifacial (Unipolar - } \\
\text { Orthogonal) }\end{array}$ & 3 & 3 & 25 \\
\hline & n8 & $1 \mathrm{a}$ & Unifacial (Orthogonal) & 2 & 1 & 13 \\
\hline & n10 & 1a-a1 & Unifacial (Unipolar) & 2 & 2 & 10 \\
\hline & $\mathrm{n} 7$ & $1 a-a b-2(a b)-a 1$ & Multifacial (Unipolar) & 3 & 3 & 21 \\
\hline & n9a & 1a-a1 & Unifacial (Bipolar) & 1 & 1 & 16 \\
\hline & $n 9 b$ & $1 a-a b-b c$ & Multifacial (Unipolar) & 3 & 3 & 25 \\
\hline
\end{tabular}

The unipolar production begun with the opening of a flat striking platform by decapping one of the extremities of the pebbles or by exploiting naturally present suitable convexities (Fig. $4 n^{\circ} 1$ ). The knapping surfaces were initially natural then gradually decorticated by parallel unipolar removals. Therefore, knapping surfaces were orthogonally generated, often by negatives of previous removals. The same scheme is observable on striking platforms. The production was carried on until suitable convexities existed. Usually, 3-4 flakes were extracted from each core but when bigger pebbles were present, such as in Montepoggiolo, a succession of three or four generation from the same striking platform is attested (Fig. 3,4n' 2 ). Overall, the flake production was achieved while maintaining appropriate convexities. The use of lateral debordant flakes, both for the creation of backed margins and as nervure guides is the technical expedient more frequently adopted to do so (Fig. 10).

In the second above-mentioned case a centripetal conception of the surfaces was applied. A single knapping surface was exploited by different directions (usually orthogonal or bipolar, more rarely centripetal sensu stricto) through a peripheral striking platform (Fig. $3 n^{\circ} 1 ; 4 n^{\circ} 1$ ). This strategy was 
applied on the rounder cobbles, especially the smallest ones, usually opened by bipolar on anvil technique. By doing so, larger knapping surfaces were made available and it was also the best way to enhance the cobbles' volume. Therefore, it is the most efficient behaviour attested in Pirro Nord (Fig. 3; Table 4). The striking platforms were mainly natural although in Montepoggiolo flat ones are attested by several refits. The latter were realized through one, or more, orthogonal removals to the knapping surface to prepare a peripheral striking platform (Fig. 4). During the reduction sequence each removal would often create new convexities (lateral and or distal) and nervures that allowed the debitage to run around the block until suitable technical criteria existed. As aforementioned, also in this case, the presence of debordant flakes is quite relevant with the aim of maintaining good angles and convexities, and to obtain backed flakes (opposed to a cutting edge) (Fig. $6 n^{\circ} 4,6,11,12 ; 7 n^{\circ} 4,8,10 ; 10$ ).

All things considered, the raw material's morphology dictates the choice of the best strategy to employ among the two. Nonetheless, both behaviours can be attested on the same core. The constant adaptation to the morphology is the scheme laying behind the process for accomplishing the production's goals.

\subsection{Flakes' analysis}

Pirro Nord and Cà Belvedere di Montepoggiolo's flakes share common features. Quadrangular nonstandardized shapes are widely attested, slightly longer than larger and with at least one cutting edge, usually on the lateral margin (Fig. 5, 6, 7). The length of Pirro Nord's flakes range between 40 and $15 \mathrm{~mm}$. The average length is $27 \mathrm{~mm}$. Width ranges from 30 to $10 \mathrm{~mm}$, with an average of $20,2 \mathrm{~mm}$. Thickness varies between 16 and $3 \mathrm{~mm}$ and the average value is $8,4 \mathrm{~mm}$. Regarding Cà Belvedere di Montepoggiolo's flakes they are longer than Pirro Nord's one. Length ranges between 78 and $11 \mathrm{~mm}$ however, for $77 \%$ of the pieces it goes from 19 to $51 \mathrm{~mm}$. The average length is $37,3 \mathrm{~mm}$. Width reaches a maximum value of 51 and a minimum of $12 \mathrm{~mm}$ with an average of $26 \mathrm{~mm}$. However, for $87 \%$ of flakes the width spans from 12 to $36 \mathrm{~mm}$. Concerning thickness, it varies from 28 to $2 \mathrm{~mm}$ with an average value of $9,3 \mathrm{~mm}$.

The dimensional range of the flakes, bearing or not cortex, is quite homogenous, confirming the shortness of the reduction sequences (Fig. 8). The cortical flakes, less attested, are related either to the bipolar technique or to the opening of new knapping surfaces. The frequency of functional flakes (with at least one cutting edge) is constant within each employed reduction sequence, indicating that the adaptation to the morphology led to an efficient production. Moreover, the presence of lateral backed margins (mainly cortical) opposed to the cutting edges can be interpreted as a researched feature for better grasping and as already mentioned, a technical expedient as well (Fig. 6, 7, 10). Several refits from Cà Belvedere di Montepoggiolo highlight this strategy as an efficient way to maintain technical criteria parallel to flake production. In this case convergent flakes could be obtained through a removal on the lateral edge of the knapping surface, thus preparing a nervure guide (Fig. $\left.7 n^{\circ} 4,5,6\right)$.

\subsection{The experimental collection}

As it happens, the experimental collection of Pirro Nord provided a great number of debordant flakes, both from the unipolar and centripetal cores (Fig. 9, 10; Table 5). These were constant in each knapping-event, 
showing specific behaviours in relations to core's exploitation but often being characterized by a lateral cutting edge opposed to the backed margin (Fig. $9 n^{\circ} 1,3,4,9$ ). In unipolar productions their function was the knapping surface's management, achieved by lowering the lateral edges of the cores while also creating nervures guide for the subsequent removals. This way, each following flake sets up a lateral convexity and a nervure guide for its consecutive removal, making it possible to easily obtain sustainable flake-lengths and cutting edges without cortex. In the centripetal sequences, cordal-like removals (Fig. $9 n^{\circ}$ 9) were often performed to maintain good convexities but since the debitage was performed through a peripheral striking platform, lateral and distal convexities were often, unintentionally, created (Fig. $9 n^{\circ} 10$, 11). This allowed the knapper to effectively run around the block and choose the best surface to eventually control the flake's morphology and its functional features. This pattern is evident especially in the case of small cores (Fig. 12). Therefore, orthogonal removals were performed alternating two distinct directions from the striking platform (Fig. $12 n^{\circ} 3$ ). The experimental collection also yielded a great number of déjeté points: corresponding to $23 \%$ of all flakes. The frequency of two orthogonal margins (the lateral and the distal one), forming a point, often adjacent to a natural backed edge, turned out to be very high in centripetal exploitation ( $36 \%$ of all déjeté points; Fig. $9 n^{\circ} 8,10-12$ ). However, these flakes were not morphologically predetermined, as seen in the archaeological record (Potì, 2012; Arzarello et al., 2016; Fig. $6 n^{\circ} 8$ ). In fact, these proved to be rather an unintentional outcome of centripetal reduction sequences, which likely produced quadrangular flakes (i.e., with orthogonal margins) (Fig. 9n 8,10,11).

The analysis of the experimental production from Pirro Nord displayed a greater affinity between the centripetal reduction sequences and the archaeological collection (Table 4). As a matter of fact, the ratio between unipolar removals and orthogonal + bipolar ones is closer when only centripetal reduction sequences are selected. This is also emphasised by a greater similarity of the flakes thus obtained (Fig. $6 n^{\circ} 6-9$; Fig. $9 n^{\circ} 7,8,10-12$ ). The centripetal exploitation of the surfaces resulted to be more efficient and quantitively rewarding when experimenting on smaller volumes and rounder morphologies.

By observing the refitting of the experimental sequences, it appears that, as stressed already, a centripetal conception of the surfaces easily leads to a better control of the flake's morphology. As a result, this may gradually generate a greater awareness in the knapper's mind during the knapping activity leading to hierarchized reduction sequences and, eventually, obtaining morphologically predetermined products. The presence of déjeté points in Pirro Nord's archaeological record (Fig. $6 n^{\circ} 8$ ) and convergent flakes from the Cà Belvedere di Montepoggiolo's one (Fig. $\left.7 n^{\circ} 4,5\right)$, may be an example of this. Short reduction sequences intensively and constantly applied on a great number of pebbles could lead to a standardized technical behaviour, modulated on the constantly changing morphology, with a potential of generating predetermined products. In conclusion, to similar morphologies can correspond identical methodological responses (Arzarello et al., 2016).

\section{The Opportunistic Debitage Of Ciota Ciara Cave \& Riparo Tagliente}

As far as it concerns the raw material selection, the same pattern can be highlighted for the opportunistic assemblages of Ciota Ciara cave and Riparo Tagliente. In the Ciota Ciara cave the vein quartz is the most 
exploited raw material not only for the opportunistic reduction sequences but also for the other knapping methods (such as Levallois and Discoid; Daffara, 2017). Blocks and nodules of different morphologies and dimensions (40-100 mm) were locally collected along riverbeds and slope deposits (Daffara et al., 2019). Since vein quartz's texture is mainly coarse, implying shorter reduction sequences, a greater importance to the presence of suitable natural convexities was given rather than to the dimensional issues. The same procurement strategies are seen in Riparo Tagliente, where a great abundance of large flint blocks and nodules of extremely good quality were available. As in the previous context, Levallois and Discoid productions are attested on the same raw material alongside with the laminar method.

\subsection{Ciota Ciara cave - Production}

In the Ciota Ciara cave the flake production started straight from the natural convexities, or arrows, of the blocks without foreseeing any core preparation or surface management. The production, then, proceeded mainly through unipolar removals eventually including new knapping surfaces or just switching them (Fig. 13; Table 4). Orthogonal and bipolar removals are less attested (Fig. 13). The use of the same knapping surface and striking platform until the abandonment of the core was rather common (Table 4). The flakes thus obtained were quadrangular in shape, yet morphologically non-standardized and with at least a cutting edge on the lateral margin (Fig. 16). According to the raw material features, a high rate of flaking accidents and the formation of irregular surfaces on the cores are frequent (Daffara, 2017). Therefore, the creation and management of suitable convexities and nervure-guides was related to the initial morphology of the blocks. The reduction sequences' length was proportioned to the initial volume of the block, but above all to its morphological flaking-predisposition. With this term we want to indicate the presence of natural suitable angle and convexities as the guiding line not only for the blocks' selection but also during the knapping activity as well. This is confirmed by the experimental collection that provided a wide sample of exhausted cores of different morphologies and dimensions. Their analysis emphasizes the absence of a specific tendency in the choice of one, or more, striking platforms and knapping surfaces to exploit (Table 6). Instead, the objectives of production were modulated considering the pre-existing convexities.

No difference was made between natural or flat striking platform since the presence of vein quartz's cortex did not affect the flaking activity. The likelihood of exploiting one single knapping surface until the abandonment of the core was rather high also considering the high percentage of natural butts. This may also prove that the production's phase corresponds to the starting of the flaking process from the natural surfaces (Table 4, 6). 
Table 6

Ciota Ciara cave. Analysis of the experimental cores. $\mathrm{N}^{\circ} \mathrm{S}$. P. indicates the final number of striking platforms on the abandoned cores. $\mathrm{N}^{\circ} \mathrm{K}$. S. indicated the final number of knapping surfaces on the abandoned cores.

\begin{tabular}{|lllllll|}
\hline Site & Core ID & $\begin{array}{l}\text { Knapping-events } \\
\text { sequence }\end{array}$ & Type of core & $\begin{array}{l}\mathbf{N}^{\circ} \\
\text { S. P. }\end{array}$ & $\begin{array}{l}\mathbf{N}^{\circ} \text { K. } \\
\text { S. }\end{array}$ & $\begin{array}{l}\mathbf{N}^{\circ} \\
\text { Flakes }\end{array}$ \\
\hline $\begin{array}{llllll}\text { Ciove Ciara } \\
\text { CC1N }\end{array}$ & 1a-a1-1b-b1 & $\begin{array}{l}\text { Multifacial (Unipolar - } \\
\text { Bipolar) }\end{array}$ & 3 & 4 & 41 \\
\cline { 2 - 7 } & CCN9-1 & 1a-ab-1c & Multifacial (Unipolar) & 2 & 3 & 3 \\
\hline CC3N & 1a-a1-1b-b1 & $\begin{array}{l}\text { Multifacial (Unipolar - } \\
\text { Bipolar) }\end{array}$ & 3 & 3 & 14 \\
\hline CCN10 & 1a-a1 & Multifacial (Unipolar) & 2 & 2 & 4 \\
\hline CCN5 & 1a-a1-1a1 & Multifacial (Unipolar) & 2 & 2 & 23 \\
\hline CCN9 & 1a-ab-ba & Multifacial (Unipolar) & 2 & 2 & 23 \\
\hline CCN7 & 1a-ab-1a1-a1-1a2 & Multifacial (Unipolar) & 2 & 2 & 27 \\
\hline CCN4b & 1a-ab & Multifacial (Unipolar) & 2 & 2 & 10 \\
\hline CCN4a & 1a-a1 & Multifacial (Unipolar) & 2 & 2 & 9 \\
\hline CCN8 & 1a-21-1all & Multifacial (Unipolar) & 1 & 1 & 11 \\
\hline CCN6 & 1a & Unifacial (Unipolar) & 1 & 1 & 18 \\
\hline CC2Nb & 1a & Unifacial (Unipolar) & 1 & 1 & 3 \\
\hline CC2Na & 1a & Unifacial (Unipolar) & 1 & 1 & 5 \\
\hline CC2N & 1a-21 & Unifacial (Unipolar) & 1 & 1 & 2 \\
\hline CCN4b1 & 1a & Unifacial (Unipolar) & 1 & 1 & 5 \\
\hline
\end{tabular}

\subsection{Ciota Ciara cave - Flakes' analysis}

Ciota Ciara's flakes are roughly quadrangular and slightly longer than larger (Fig. 5). Length ranges between 70 and $14 \mathrm{~mm}$ with an average of $33,5 \mathrm{~mm}$. Width spans from 12 to $66 \mathrm{~mm}$ however, $82 \%$ of flakes' width ranges from 12 to 32 . The width's average is 25,5 . Regarding thickness, it goes from 4 to 24 $\mathrm{mm}$ with an average value of $12,5 \mathrm{~mm}$. The flakes are characterized by a lateral cutting edge frequently opposed to a backed margin (Fig. $16 n^{\circ} 1,3,5,6$; Fig. 18). The presence of guiding arrises is usually related to a single unipolar removal or, more rarely, by a portion of cortex (Fig. $16 n^{\circ} 1,3,5,8$ ). Generally, most of the flakes show only one negative, suggesting that knapping surfaces were not that large, being exploited through few removals until the exhaustion of the natural convexities. In this way, natural edges were used as a technical expedient to achieve functional flake production and create nervure guides. 
Therefore, the frequency of debordant flakes is quite high (Fig. 18). Orthogonal and bipolar flaking resulted to be sporadically employed (Fig. 13). The cores and flakes attesting these strategies (Fig. 14n 2), however, are not different from the record, fitting well in the same operative scheme of subordination and adaptation to the morphology which comprise the whole opportunistic production of the Ciota Ciara cave. As a sign of this, the experimental's reduction sequences occasionally presented knapping surfaces exploited from several directions, but this was not matched by the flake's removals analysis which, instead, presents the same trend of the archaeological ones (Table 4, 6; Fig. 13, 15, 17). On experimental basis, the functionality-rate of the flakes proved to be higher on the smallest and thinnest ones. This, however, is not validated by the archaeological sample attesting, on the other hand, a homogeneous distribution of functional flake within the dimensional range. Therefore, the accomplishment of the production's goals was constant along the entire reduction process, without the need for specific morphodimensional criteria.

Once again, the high flexibility towards morphologies and volumes of blocks and cores emerge as the main aspect characterizing the opportunistic assemblages. The presence of Levallois and Discoid productions within the context proves, on one side, that the exploitation of raw materials qualitatively regarded as inferior does not invalidate the possibility of using more complex flaking methods. On the other side, it underlines how the opportunistic debitage persists during middle Palaeolithic resulting in being as much as an efficient and independent method (if compared to Levallois and Discoid) replicated through several operative knapping schemes (i.e., unipolar, orthogonal, centripetal, bipolar) for the manufacturing of functional products.

\subsection{Riparo Tagliente}

Concerning Riparo Tagliente's opportunistic assemblage, the aim was always flake production achieved through a constant adaptation to the morphological criteria. Since better and larger blocks were available (nodules and fluvial cobbles), the reduction sequences were longer and more complex (Table 4; Fig. 23). As a matter of fact, these aspects enhanced the possibility of exploiting, at the same time or individually, more surfaces through multifacial removals (unipolar, orthogonal, bipolar, and centripetal s.s.), until the complete depletion of the existent convexities. This determined, eventually, the abandonment of large dimensions' cores, still presenting suitable surfaces for pursuing the exploitation (Fig. 23). The great abundance of such a good raw material within the site, might explain this behaviour (Arzarello, 2003). Of course, the presence of small massively exploited cores as well, suggests that the production could be quantitively remarking despite anything else.

The initial morphology, again, dictated how the production's goals were achieved. This resolved in a dual case scenario to produce non-standardized quadrangular flakes, slightly elongated and with at least one cutting edge (Fig. 5, 24). In the first case, a unipolar-multifacial debitage was set up while in the latter a centripetal one occurred. These two strategies were not separately employed but constantly linked and rotated on the same core according to the evolving morphologies. The length of these flakes ranges between 20 and $70 \mathrm{~mm}$ with $91 \%$ of them ranging from 20 to $50 \mathrm{~mm}$. The average length is $36 \mathrm{~mm}$. 
Concerning width, it spans from 12 to $65 \mathrm{~mm}$ but $86 \%$ is included in a $17-42 \mathrm{~mm}$ range. The average width is $30,2 \mathrm{~mm}$. Thickness varies from 4 to $19 \mathrm{~mm}$ with an average of $8,6 \mathrm{~mm}$.

\subsection{Riparo Tagliente - Production}

The unipolar production was carried on larger nodules or on particularly elongated ones, where the longitudinal axis was often employed as the knapping surface. In this case the presence of suitable natural convexities was one of the requirements for the opening of the flaking activity. In fact, most of the nodules presented exposed surfaces due to natural fractures that could speed up the extraction process (Fig. 21). Otherwise, a single cortical flake was needed in order to prepare the knapping surface. Concerning striking platforms, the same pattern can be attested. The opening of a flat one was necessary when an already existing one was lacking on the initial morphology of the blocks. Elongated laminar-like flakes where thus obtained, more frequently presenting a debordant edge on the lateral margin rather than on the distal one (Fig. 20, $24 n^{\circ} 1,2$ ). The cutting edge often corresponded to the scar left by previous removals. The aim was to gradually enlarge the knapping surface, removing the cortex, and thus involving the other core's faces. The formation of nervure-guides happened simultaneously to the flake's extraction being equally exploited as natural edges. These aspects were functional to the flakes' length, optimizing the knapping surface's productivity in both a quantitative and qualitative way. As stressed above, this strategy resulted, eventually, in semi-tournant behaviours involving, initially, natural edges then by progressively exploiting ones created during the production, recalling the laminar conception. As far as the core's volume decreased a multidirectional flaking could be initiated (Table 4; Fig. 22, 23). Therefore, the switching between the striking platforms and knapping surfaces was rather frequent and useful to the preservation of the technical criteria. For this reason, orthogonal and bipolar debitage were likely to happen, both leading to a centripetal conception of knapping surfaces. That is: the same extraction's surface was more frequently knapped as the core's volume decreased. At this stage, the flakes were gradually smaller and quadrangular in shape bearing no cortex at all. An increase of the cutting edges on the distal margins can be observed. This pattern was then repeated until the core was no further exploitable.

When large fluvial pebbles were collected and/or flatten and rounder surfaces available, a centripetal flaking was possible for starting the production. In this way a pre-existing peripheral striking platform was available (although a cortical flake may have been required to initiate the debitage) resulting in an optimization of the raw material's economy (Fig. $23 n^{\circ} 2$ ). The production focused on parallel removals which gradually involved the entire surface allowing a better control over the flakes' morpho-technical criteria, granted by an easier management of the convexities, and guiding arrises. In this case an orthogonal debitage could be highlighted in the initial stages of the unipolar productions as well, as an expedient to create distal and lateral convexities (Fig. $24 n^{\circ} 8,9,10$ ). These ones, together with the unipolar nervure-guides guaranteed that each removal would cover the entire knapping surface's length, determining also an elongated and regular cutting edge on the flakes. As previously stated, a centripetal debitage (mainly orthogonal and bipolar) might have occurred during the final phases of the unipolar cores to deal with the unlikelihood of exploiting a surface from one direction. In this way alternated removals were more efficient and productively rewarding. 
In conclusion, Riparo Tagliente's strategies proved to be efficient in terms of production of flakes presenting at least one cutting edge. The flakes' functionality rate appeared to be constant within each core, despite the technical behaviours employed to obtain them. Even with the gradual decrease of the flakes' length the same pattern can be attested confirming, overall, a well-organized production. Both on the archaeological record and the experimental one, a global increase of the cutting edges per flake (especially on the distal margins) was observed simultaneously to a reduction of the whole length and to a decrease of the debordant edges' frequency. However, this was seemingly not a relevant production's goal but still confirms the reliability of the reduction processes even on the final stages of the cores' exploitation. The experimental collection also provided a great number of déjeté points, especially through a centripetal debitage. Nevertheless, they resulted to be an unintentional outcome of the flaking processes, mainly due to the convexities management and the possibility of obtaining quadrangular flakes rather than to a dedicated flaking scheme.

\subsection{Riparo Tagliente - experimental collection}

The analysis of the experimental reduction sequences matched the archaeological ones (Table 7; Fig. 26). Both, massively exhausted cores, and ones of bigger dimensions, still presenting a suitable volume to exploit were present. Multiple flaking-events involving all block's surfaces or single ones carried on until the core's abandonment were evidenced. The switching between the striking platforms and knapping surfaces was frequent as well especially as the core's dimensions decreased (Table 7). As a matter of fact, on the same core, a centripetal debitage often developed into a unidirectional one, or vice versa leading to short reduction sequences. In this case, it was the experimental work's merit to verify and validate how the morphologies could dictate how the objectives of productions were achieved, generating a wide number of diversified operative schemes still originated from the same mental scheme. For this reason, from a methodological perspective and given the definition of method used for this work "Le mot méthode revoit uniquement à l'étape de production: liaison entre la représentation abstraite de l'objectif et sa concrétisation. ... il s'agit de l'ensemble des démarches raisonnées -schéma opératoire- suivi pour réaliser les objectifs fixés" (Boëda, 1994), there is no such difference in the several operative schemes (i.e. unipolar, centripetal or multidirectional debitage) used to achieve flake production since the purpose they are applied for (i.e. mental scheme, method), remains the same. It is the opportunistic method which differentiate itself in multiple types of debitage according to the raw material morphology and quality. 
Table 7

Riparo Tagliente. Analysis of the experimental cores. $\mathrm{N}^{\circ} \mathrm{S}$. P. indicates the final number of striking platforms on the abandoned cores. $N^{\circ} \mathrm{K}$. S. indicated the final number of knapping surfaces on the abandoned cores.

\begin{tabular}{|lllllll|}
\hline Site & $\begin{array}{l}\text { Core } \\
\text { ID }\end{array}$ & $\begin{array}{l}\text { Knapping-events } \\
\text { sequence }\end{array}$ & Type of core & $\begin{array}{l}\mathbf{N}^{\circ} \\
\text { S. P. }\end{array}$ & $\begin{array}{l}\mathbf{N}^{\circ} \text { K. } \\
\text { S. }\end{array}$ & $\begin{array}{l}\mathbf{N}^{\circ} \\
\text { Flakes }\end{array}$ \\
\hline $\begin{array}{l}\text { Riparo } \\
\text { Tagliente }\end{array}$ & RT1N & 1a-a1-1b-a11-1c & Multifacial (Unipolar) & 3 & 3 & 44 \\
& RT2N & 1a-ab-bc-cd & $\begin{array}{l}\text { Multifacial (Unipolar - } \\
\text { Orthogonal) }\end{array}$ & 3 & 3 & 41 \\
\hline & RT3N & 1a-a1-1b-1c & Multifacial (Unipolar) & 3 & 3 & 49 \\
\hline RT5N & 1a-a1-1al-a1l-1all & $\begin{array}{l}\text { Multifacial (Unipolar - } \\
\text { Orthogonal) }\end{array}$ & 4 & 5 & 40 \\
\hline RT6N & 1a-a1 & Multifacial (Unipolar) & 2 & 2 & 20 \\
\hline RT7N & 1a-ab-1b-a1-1al & Multifacial (Unipolar) & 2 & 2 & 43 \\
\hline RT8N & 1a-a1-1b-b1 & Multifacial (Unipolar) & 2 & 2 & 18 \\
\hline RT9N & 1a-ab & Multifacial (Unipolar) & 2 & 2 & 25 \\
\hline RT10N & 1a & Unifacial (Centripetal) & 1 & 1 & 54 \\
\hline RT11N & $\begin{array}{l}\text { 1a-ab-ac-ba-abl-bal- } \\
\text { abll }\end{array}$ & Multifacial (Unipolar) & 3 & 3 & 78 \\
\hline
\end{tabular}

The presence of more complex flaking methods within the Mousterian sequence of Riparo Tagliente (alongside the opportunistic debitage), implying either a surfaces' hierarchization (Levallois) or a strong subordination of the raw material's morphology to specific technical criteria (such as discoid and laminar), certainly played an influencing role in how the opportunistic sequences were achieved resulting in a greater flaking-technical awareness. As a sign of this, several experimental cores showed a greater affinity both with discoid reduction (Fig. $26 n^{\circ} 1$ ) sequences and the laminar ones. In the first case, the centripetal debitage was addressed, regarding the convexities' management and the use of cordal-like removals. In the latter, the experimental cores presenting an elongated morphology together with a low width, were exploited through semi-tournant removals, often implying the presence of central nervureguide (like a crest; Fig. $25 n^{\circ} 3,5$ ).

For these reason, one can assume, in a broader chronological perspective, that it was indeed the great versatility of the opportunistic debitage to represent, as seen in its earliest evidence (such as in Pirro Nord and Cà Belvedere di Montepoggiolo), the groundwork for the rising of such highly specialized and predetermined flaking method. By this, it is meant that starting from a deep subordination to morphological criteria to achieve an efficient functional flake production (which is the basic being of any flaking activity) a greater technical awareness may arise, leading to a possible subordination of the 
morphology itself to the technical criteria. As a matter of fact, this aspect, represent the starting point for Levallois and Discoid methods. However, their success, from middle Palaeolithic onward, did not prevent the opportunistic debitage to persist during the whole Pleistocene, both in a qualitative and quantitative way.

\section{Conclusions}

The delineation of the opportunistic method interests a wide chronological frame being all the way through characterized by a strong adaptation and subordination to the morphology and quality of the raw materials locally available, as observed in all the contexts where it was identified. It is defined as "a method oriented to raw materials' massive exploitation without implying either a core's, or any surface, preparation. The striking platforms and knapping surfaces are created as far as the flaking activity is carried on. [...] The opportunistic debitage include an infinite range of variants always coming from the same common operative scheme" (traduced by Arzarello, 2003). Its flexibility it allows the modulation into different technical behaviours, constantly aimed to the extraction of functional products, in a highly efficient approach. The easily replicability of the operative scheme through the technical gesture, together with an optimization of the block's volume, is the methodological substratum behind the mental process. This, for the oldest contexts, may give rise to a methodological and cultural potential that may represent the beginning of more complex flaking methods. The occurrence of predetermined-like products coming from the centripetal reduction sequences of Pirro Nord and Cà Belvedere di Montepoggiolo may be an example of this process. On the other hand, for the most recent periods such as middle Palaeolithic, the opportunistic debitage persists as a reliable and independent flaking method. In these cases, it often coexists with Levallois, Discoid and laminar productions, standing as one of the possible behavioural variables of the human groups. Still identifiable on an archaeological basis through its technical criteria, even if subjected to different chronological, environmental, and cultural aspects (this last one always hardly perceived within the analysis of any lithic industry).

In conclusion, the term "opportunism" does not represent just a mere application of the flaking criteria alongside a great technical skill completely disentangled from any mental scheme. As observed in this work, its flexibility and capability to be efficiently adopted through different chronological and cultural phases, always maintaining a steady mental scheme, are the main features that outline a flaking method by definition. Therefore, the opportunistic debitage may be, indeed, the "link between the abstract representation of the object and its realization" (traduced by Boëda, 1994) since it connects a series of technical behaviours and gestures for its realization (Tixier et al., 1980) not only in a synchronic perspective but mostly in a diachronic one. However, it must be reminded that, as a flaking method, it will always be a partial aspect of the human groups' material culture: useful for the identification and interpretation of specific behaviours but far from being its unique constituent.

\section{Declarations}

\section{Supplementary information}


Supplementary information is available for this paper at:

https://zenodo.org/record/4228014\#.X9t6v9hKhPY

\section{Acknowledgements}

Version 9 of this preprint has been peer-reviewed and recommended by Peer Community In Archaeo (https://doi.org/10.24072/pci.archaeo.100007)

\section{Conflict of interest disclosure}

The authors of this article declare that they have no financial conflict of interest with the content of this article.

\section{References}

Agam, A., Marder, O., Barkai, R., 2015. Small flake production and lithic recycling at late acheulian revadim, Israel. Quaternary International 361, 46-60. doi:10.1016/j.quaint.2014.06.070

Angelucci, D.E., Zambaldi, M., Tessari, U., Vaccaro, C., Arnaud, J., Berruti, G.L.F., Daffara, S., Arzarello, M., 2019. New insights on the Monte Fenera Palaeolithic, Italy: Geoarchaeology of the Ciota Ciara cave. Geoarchaeology 34, 413-429. doi:10.1002/gea.21708

Arnaud, J., Peretto, C., Panetta, D., Tripodi, M., Fontana, F., Arzarello, M., Thun Hohenstein, U., Berto, C., Sala, B., Oxilia, G., Salvadori, P.A., Benazzi, S., 2016. A reexamination of the Middle Paleolithic human remains from Riparo Tagliente, Italy. Quaternary International 425, 437-444.

doi:10.1016/j.quaint.2016.09.009

Arzarello, M., 2003. Contributo allo studio del comportamento tecno-economico dell'uomo di Neandertal: I'industria litica della serie musteriana del Riparo Tagliente (Stallavena di Grezzana, Vr, Italia). Università degli Studi di Ferrara.

Arzarello, M., Berto, C., Casini, A.I., Berruti, G.L.F., Bertè, D., Daffara, S., Berruto, G., Arzarello, M., Berruti, G.L.F., Berruto, G., Bertè, D., Berto, C., Casini, A.I., 2014. The Mousterian lithic assemblage of the Ciota Ciara cave (Piedmont, Northern Italy): exploitation and conditioning of raw materials. Journal of Lithic Studies 1. doi:10.2218/jls.v1i2.1102

Arzarello, M., Weyer, L. De, Peretto, C., 2016. The first European peopling and the Italian case: Peculiarities and "opportunism." Quaternary International 393, 41-50. doi:10.1016/j.quaint.2015.11.005

Aureli, D., Rocca, R., Lemorini, C., Modesti, V., Scaramucci, S., Milli, S., Giaccio, B., Marano, F., Palombo, M.R., Contardi, A., 2016. Mode 1 or mode 2? "Small tools" in the technical variability of the European Lower Palaeolithic: The site of Ficoncella (Tarquinia, Lazio, central Italy). Quaternary International 393, 169-184. doi:10.1016/j.quaint.2015.07.055 
Barsky, D., Garcia, J., Martínez, K., Sala, R., Zaidner, Y., Carbonell, E., Toro-Moyano, I., 2013. Flake modification in European Early and Early-Middle Pleistocene stone tool assemblages. Quaternary International 316, 140-154. doi:10.1016/j.quaint.2013.05.024

Bartolomei, G., Broglio, A., Cattani, L., Cremaschi, M., Guerreschi, A., Mantovani, E., Peretto, C., Sala, B., 1982. I depositi wurmiani del Riparo Tagliente.

Berto, C., Bertè, D., Luzi, E., López-García, J.M., Pereswiet-Soltan, A., Arzarello, M., 2016. Small and large mammals from the Ciota Ciara cave (Borgosesia, Vercelli, Italy): An Isotope Stage 5 assemblage. Comptes Rendus - Palevol 15, 669-680. doi:10.1016/j.crpv.2015.05.014

Boëda, E., 1993. Le débitage discoïde et le débitage Levallois récurrent centripède 392-404.

Boëda, E., 1994. Le Concept Levallois: variabilité des méthodes. Monographie du CRA; 9280.

Boëda, E., 2013. Techno-logique Technologie 259.

Bourguignon, L., 1997. Le Moustérien de type Quina: nouvelle définition d'une entité technique. Doctorat en Lettres et Sciences humaines, spécialité préhistoire.

Bourguignon, L., Faivre, J.-P., Turq, A., 2004. Ramification des chaînes opératoires: une spécificité du Moustérien. Paléo 16, 37-48.

Bourguignon, L., Barsky, D., Ivorra, J., Weyer, L. de, Cuartero, F., Capdevila, R., Cavallina, C., Oms, O., Bruxelles, L., Crochet, J.Y., Garaizar, J.R., 2016. The stone tools from stratigraphical unit 4 of the Bois-deRiquet site (Lézignan-la-Cèbe, Hérault, France): A new milestone in the diversity of the European Acheulian. Quaternary International 411, 160-181. doi:10.1016/j.quaint.2016.01.065

Busa, F., Gallo, L.M., Dellarole, E., 2005. L’attività di ricerca nelle grotte del Monte Fenera. D'acqua e di pietra. Il monte Fenera e le sue collezioni museali 218-223.

Cavicchi, R., 2018. Biocronologia, paleoecologia e paleoambiente della grotta Ciota Ciara (Borgosesia, Vercelli, Piemonte): nuovi dati dalla sequenza a grandi mammiferi. Università degli Studi di Ferrara.

Cheheb, R.C., Arzarello, M., Arnaud, J., Berto, C., Cáceres, I., Caracausi, S., Colopi, F., Daffara, S., Canini, G.M., Huguet, R., Karambatsou, T., Sala, B., Zambaldi, M., Berruti, G.L.F., 2019. Human behavior and Homo-mammal interactions at the first European peopling: new evidence from the Pirro Nord site (Apricena, Southern Italy). Science of Nature 106. doi:10.1007/s00114-019-1610-4

Daffara, S., 2017. Non-Flint raw materials in the European Middle Palaeolithic: variability of Levallois and discoid knapping methods and study of the suppy areas. 490.

Daffara, S., Berruti, G.L.F., Berruto, G., Eftekhari, N., Vaccaro, C., Arzarello, M., 2019. Raw materials procurement strategies at the Ciota Ciara cave: New insight on land mobility in north-western Italy during 
Middle Palaeolithic. Journal of Archaeological Science: Reports 26. doi:10.1016/j.jasrep.2019.101882

Despriée, J., Voinchet, P., Tissoux, H., Moncel, M.H., Arzarello, M., Robin, S., Bahain, J.J., Falguères, C., Courcimault, G., Dépont, J., Gageonnet, R., Marquer, L., Messager, E., Abdessadok, S., Puaud, S., 2010. Lower and middle Pleistocene human settlements in the Middle Loire River Basin, Centre Region, France. Quaternary International 223-224, 345-359. doi:10.1016/j.quaint.2009.07.019

Despriée, J., Moncel, M.H., Arzarello, M., Courcimault, G., Voinchet, P., Bahain, J.J., Falguères, C., 2018. The 1-million-year-old quartz assemblage from Pont-de-Lavaud (Centre, France) in the European context. Journal of Quaternary Science 33, 639-661. doi:10.1002/jqs.3042

Fedele, F., 1966. La stazione paleolitica del Monfenera (Borgosesia). Rivista di studi liguri 5-105.

Fontana, F., Guerreschi, A., Liagre, J., 2002. Riparo Tagliente. La serie epigravettiana.

Forestier, H., 1993. Le Clactonien: mise en application d'une nouvelle méthode de débitage s'inscrivant dans la variabilité des systèmes de production lithique du Paléolithique ancien. Paléo 5, 53-82. doi:10.3406/pal.1993.1104

Gallotti, R., Peretto, C., 2015. The Lower/early Middle Pleistocene small débitage productions in Western Europe: New data from Isernia La Pineta t.3c (Upper Volturno Basin, Italy). Quaternary International 357, 264-281. doi:10.1016/j.quaint.2014.06.055

García-Medrano, P., Ollé, A., Mosquera, M., Cáceres, I., Carbonell, E., 2015. The nature of technological changes: The Middle Pleistocene stone tool assemblages from Galería and Gran Dolina-subunit TD10.1 (Atapuerca, Spain). Quaternary International 368, 92-111. doi:10.1016/j.quaint.2015.03.006

Gijn, A. Van, 1989. The wear and tear of flint: principles of functional analysis applied to Dutch Neolithic assemblages.

Giusti, D., Arzarello, M., 2016. The need for a taphonomic perspective in spatial analysis: Formation processes at the Early Pleistocene site of Pirro Nord (P13), Apricena, Italy. Journal of Archaeological Science: Reports 8, 235-249. doi:10.1016/j.jasrep.2016.06.014

Gliozzi, E., Abbazzi, L., Argenti, P., Azzaroli, A., Caloi, L., Capasso Barbato, L., Stefano, G. Di, Esu, D., Ficcarelli, G., Girotti, O., Kotsakis, T., Masini, F., Mazza, P., Mezzabotta, C., Palombo, M.R., Petronio, C., Rook, L., Sala, B., Sardella, R., Zanalda, E., Torre, D., 1997. Biochronology of selected mammals, molluscs and ostracods from the middle pliocene to the late pleistocene in Italy. The state of the art. Rivista Italiana di Paleontologia e Stratigrafia 103, 369-388.

Grimaldi, S., Santaniello, F., Angelucci, D.E., Bruni, L., Parenti, F., 2020. A Techno-Functional Interpretation of the Lithic Assemblage from Fontana Ranuccio (Anagni, Central Italy): an Insight into a MIS 11 Human Behaviour. Journal of Paleolithic Archaeology. doi:10.1007/s41982-020-00064-3 
Inizan, M.-L., Reduron, M., Roche, H., Tixier, J., 1995. Technologie de la pierre taillée, suivi par un dictionnaire multilingue allemand, anglais, arabe, espagnol, français, grec, italien, portugais, Préhistoire de la pierre taillée; 4 .

Laplace, G., 1977. Notes de typologie analytique. Orientation de l'objet et rectangle minimal, Dialektikê. Cahiers de typologie analytique 32-53. doi:10.5281/zenodo.2584046

Lombera-Hermida, A. de, Rodríguez-Álvarez, X.P., Peña, L., Sala-Ramos, R., Despriée, J., Moncel, M.H., Gourcimault, G., Voinchet, P., Falguères, C., 2016. The lithic assemblage from Pont-de-Lavaud (Indre, France) and the role of the bipolar-on-anvil technique in the Lower and Early Middle Pleistocene technology. Journal of Anthropological Archaeology 41, 159-184. doi:10.1016/j.jaa.2015.12.002

López-García, J.M., Luzi, E., Berto, C., Peretto, C., Arzarello, M., 2015. Chronological context of the first hominin occurrence in southern Europe: The Allophaiomys ruffoi (Arvicolinae, Rodentia, Mammalia) from Pirro 13 (Pirro Nord, Apulia, southwestern Italy). Quaternary Science Reviews 107, 260-266. doi:10.1016/j.quascirev.2014.10.029

Martínez, K., Garcia Garriga, J., 2016. On the origin of the European Acheulian. Journal of Anthropological Archaeology 44, 87-104. doi:10.1016/j.jaa.2016.09.003

Mathias, C., Bourguignon, L., 2020. Cores-on-flakes and ramification during the middle palaeolithic in Southern France: A gradual process from the early to late middle palaeolithic? Journal of Archaeological Science: Reports 31, 102336. doi:10.1016/j.jasrep.2020.102336

Mathias, C., Bourguignon, L., Brenet, M., Grégoire, S., Moncel, M.H., 2020. Between new and inherited technical behaviours: a case study from the Early Middle Palaeolithic of Southern France. Archaeological and Anthropological Sciences 12. doi:10.1007/s12520-020-01114-1

Moncel, M.-H., Arzarello, M., Peretto, C., 2016. The Hoslteinian period in Europe (MIS 11-9). Quaternary International 409, 1-8. doi:10.1016/j.quaint.2016.06.006

Moncel, M.-H., Despriée, J., Courcimaut, G., Voinchet, P., Bahain, J.-J., 2020a. La Noira Site (Centre, France) and the Technological Behaviours and Skills of the Earliest Acheulean in Western Europe Between 700 and 600 ka. Journal of Paleolithic Archaeology. doi:10.1007/s41982-020-00049-2

Moncel, M.H., 2010. Oldest human expansions in Eurasia: Favouring and limiting factors. Quaternary International 223-224, 1-9. doi:10.1016/j.quaint.2010.02.016

Moncel, M.H., Despriée, J., Voinchet, P., Tissoux, H., Moreno, D., Bahain, J.J., Courcimault, G., Falguères, C., 2013. Early evidence of acheulean settlement in northwestern Europe - La noira site, a 700000 year-old occupation in the center of France. PLoS ONE 8. doi:10.1371/journal.pone.0075529

Moncel, M.H., Arzarello, M., Theodoropoulou, A., Boulio, Y., 2014. Variabilité de l'Acheuléen de plein air entre RhÔne et Loire (France). Anthropologie (France) 118, 408-436. doi:10.1016/j.anthro.2014.10.002 
Moncel, M.H., Arzarello, M., Boëda, É., Bonilauri, S., Chevrier, B., Gaillard, C., Forestier, H., Yinghua, L., Sémah, F., Zeitoun, V., 2018. The assemblages with bifacial tools in Eurasia (first part). What is going on in the West? Data on western and southern Europe and the Levant. Comptes Rendus - Palevol 17, 45-60. doi:10.1016/j.crpv.2015.09.009

Moncel, M.H., Santagata, C., Pereira, A., Nomade, S., Bahain, J.J., Voinchet, P., Piperno, M., 2019. Correction: A biface production older than 600 ka ago at Notarchirico (Southern Italy) contribution to understanding early Acheulean cognition and skills in Europe (PLoS ONE (2019) 14: 9 (e0218591) DOI: 10.1371/journal.pone.0218591). PLoS ONE. doi:10.1371/journal.pone.0224603

Moncel, M.H., Ashton, N., Arzarello, M., Fontana, F., Lamotte, A., Scott, B., Muttillo, B., Berruti, G., Nenzioni, G., Tuffreau, A., Peretto, C., 2020b. Early Levallois core technology between Marine Isotope Stage 12 and 9 in Western Europe. Journal of Human Evolution 139. doi:10.1016/j.jhevol.2019.102735

Muttoni, G., Scardia, G., Kent, D. V., Morsiani, E., Tremolada, F., Cremaschi, M., Peretto, C., 2011. First dated human occupation of Italy at $\sim 0.85 \mathrm{Ma}$ during the late Early Pleistocene climate transition. Earth and Planetary Science Letters 307, 241-252. doi:10.1016/j.epsl.2011.05.025

Ollé, A., Mosquera, M., Rodríguez, X.P., Lombera-Hermida, A. de, García-Antón, M.D., García-Medrano, P., Peña, L., Menéndez, L., Navazo, M., Terradillos, M., Bargalló, A., Márquez, B., Sala, R., Carbonell, E., 2013. The Early and Middle Pleistocene technological record from Sierra de Atapuerca (Burgos, Spain). Quaternary International 295, 138-167. doi:10.1016/j.quaint.2011.11.009

Parfitt, S.A., Snelling, A.J., Evans, A.A., Jacobi, R.M., 2008. Further discoveries of Lower Palaeolithic Stone tools in the Cromer forest-bed formation at Pakefield-Kessingland.

Pavia, M., Zunino, M., Coltorti, M., Angelone, C., Arzarello, M., Bagnus, C., Bellucci, L., Colombero, S., Marcolini, F., Peretto, C., Petronio, C., Petrucci, M., Pieruccini, P., Sardella, R., Tema, E., Villier, B., Pavia, G., 2012. Stratigraphical and palaeontological data from the Early Pleistocene Pirro 10 site of Pirro Nord (Puglia, south eastern Italy). Quaternary International 267, 40-55. doi:10.1016/j.quaint.2010.12.019

Pereira, A., Nomade, S., Shao, Q., Bahain, J.J., Arzarello, M., Douville, E., Falguères, C., Frank, N., Garcia, T., Lembo, G., Muttillo, B., Scao, V., Peretto, C., 2016. 40Ar/39Ar and ESR/U-series dates for Guado San Nicola, Middle Pleistocene key site at the Lower/Middle Palaeolithic transition in Italy. Quaternary Geochronology 36, 67-75. doi:10.1016/j.quageo.2016.08.005

Peretto, C., Amore, F.O., Antoniazzi, A., Antoniazzi, A., Bahain, J.J., Cattani, L., Cavallini, E., Esposito, P., Falguères, C., Gagnepain, J., Hedley, I., Laurent, M., Lebreton, V., Longo, L., Milliken, S., Monegatti, P., Ollé, A., Pugliese, N., Renault-Miskovsky, J., Sozzi, M., Ungaro, S., Vannucci, S., Vergès, J.M., Wagner, J.-J., Yokoyama, Y., 1998. L'industrie lithique de Ca' Belvedere di Monte Poggiolo: Stratigraphie, Matière Première, Typologie, Remontage et Traces d'Utilisation. L' Anthropologie 102, 343-465. 
Peretto, C., Arzarello, M., Bahain, J.J., Boulbes, N., Dolo, J.M., Douville, E., Falguères, C., Frank, N., Garcia, T., Lembo, G., Moigne, A.M., Muttillo, B., Nomade, S., Pereira, A., Rufo, M.A., Sala, B., Shao, Q., Thun Hohenstein, U., Tessari, U., Turrini, M.C., Vaccaro, C., 2016. The Middle Pleistocene site of Guado San Nicola (Monteroduni, Central Italy) on the Lower/Middle Palaeolithic transition. Quaternary International 411, 301-315. doi:10.1016/j.quaint.2015.11.056

Potì, A., 2012. Approccio morfo-geometrico allo studio delle schegge debordanti déjeté del sito di Pirro Nord (Apricena, Foggia). University of Ferrara.

Preece, R.C., Parfitt, S.A., 2012. The Early and early Middle Pleistocene context of human occupation and lowland glaciation in Britain and northern Europe. Quaternary International 271, 6-28. doi:10.1016/j.quaint.2012.04.018

Ricci Lucchi, F., Colalongo, M.L., Cremonini, G., Gasperi, G., laccarino, S., Papani, G., Raffi, S., Rio, D., Papini, G., 1982. Evoluzione sedimentaria e paleogeografica nel margine appenninico. Guida alla geologia del margine appenninico-padano. Soc. Geol. It 17-46.

Rocca, R., 2016. First settlements in Central Europe: Between originality and banality. Quaternary International 409, 213-221. doi:10.1016/j.quaint.2015.08.066

Rocca, R., Abruzzese, C., Aureli, D., 2016. European Acheuleans: Critical perspectives from the East. Quaternary International 411,402-411. doi:10.1016/j.quaint.2016.01.025

Romagnoli, F., Gómez de Soler, B., Bargalló, A., Chacón, M.G., Vaquero, M., 2018. Here and now or a previously planned strategy? Rethinking the concept of ramification for micro-production in expedient contexts: Implications for Neanderthal socio-economic behaviour. Quaternary International 474, 168181. doi:10.1016/j.quaint.2017.12.036

Rossoni-Notter, E., Notter, O., Simone, S., Simon, P., 2016. Acheulean technical behaviors in Aldène cave (Cesseras, Hérault, France). Quaternary International 409, 149-173. doi:10.1016/j.quaint.2015.11.016

Santagata, C., 2016. Operating systems in units B and E of the Notarchirico (Basilicata, Italy) ancient Acheulean open-air site and the role of raw materials. Quaternary International 411, 284-300. doi:10.1016/j.quaint.2015.12.074

Santagata, C., Moncel, M.H., Raynal, J.P., 2017. Les Néanderthaliens et les roches volcaniques. Opportunisme ou gestion optimisée ? Comptes Rendus - Palevol 16, 474-487. doi:10.1016/j.crpv.2016.12.001

Thun Hohenstein, U., Peretto, C., 2005. The exploitation of the faunal remains in the Mousterian levels at Riparo Tagliente (Verona, Italy). International Series 1364, 261-268.

Tixier, J., Inizan, M.-L., Roche, H., 1980. Préhistoire de la pierre taillée. 1. Terminologie et technologie, 1980 1. 
Vaquero, M., Romagnoli, F., 2018. Searching for Lazy People: the Significance of Expedient Behavior in the Interpretation of Paleolithic Assemblages. Journal of Archaeological Method and Theory 25, 334367. doi:10.1007/s10816-017-9339-x

Vietti, A., 2016. Combined Electron Spin Resonance and U-series Dating (ESR/U-series) of Fossil Tooth Enamel: Application to Dental Remains from Different Palaeolithic Italian Sites.

\section{Figures}

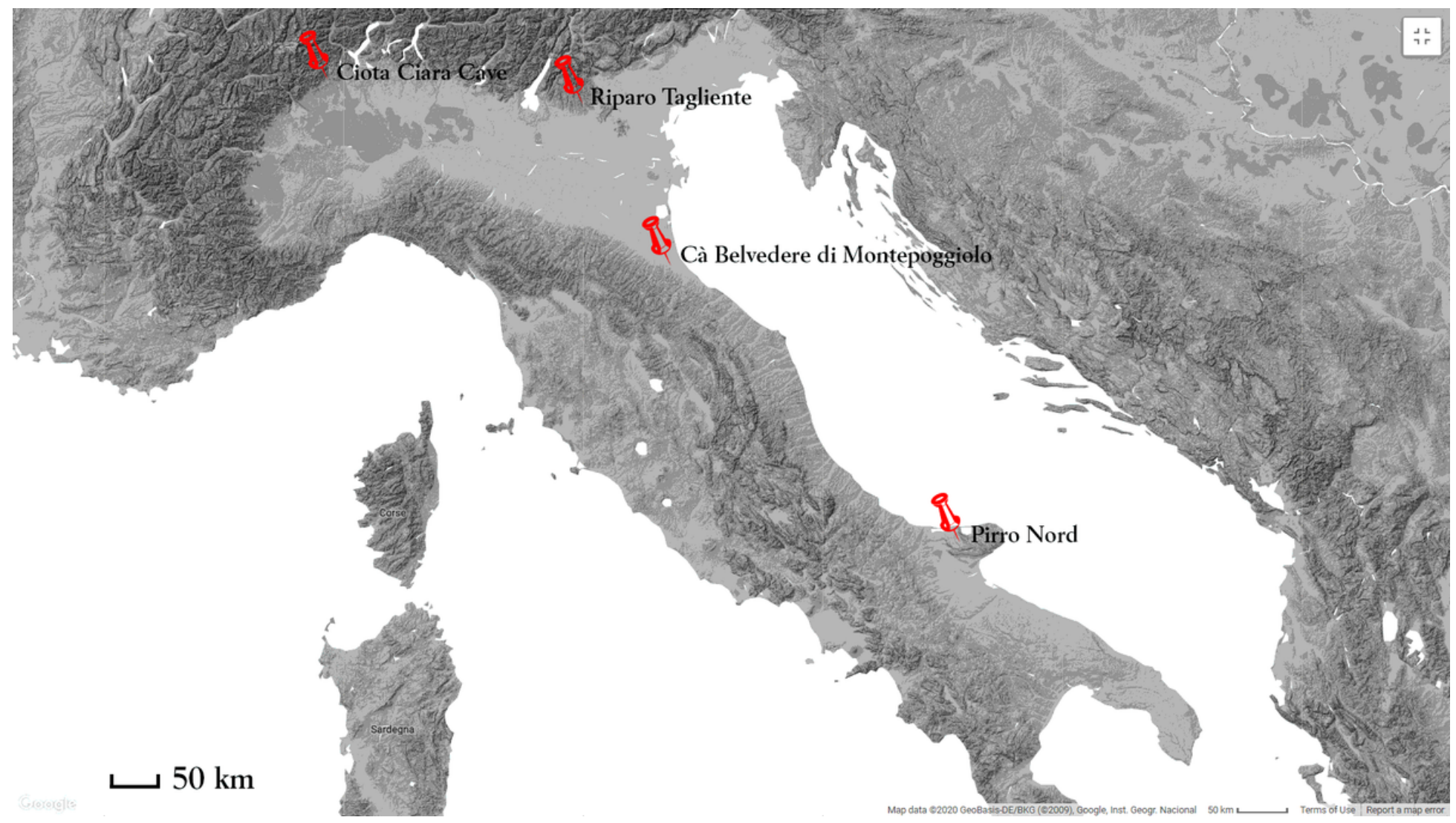

\section{Figure 1}

Map showing the location of the sites analysed in this work. 


\begin{tabular}{|c|c|c|c|}
\hline \multirow[b]{2}{*}{ Sequence } & \multicolumn{3}{|c|}{ Knapping Events } \\
\hline & $\begin{array}{l}\text { Striking } \\
\text { Platform }\end{array}$ & $\begin{array}{c}\text { Knapping } \\
\text { Surface }\end{array}$ & $\begin{array}{c}\text { Flakes } \\
\text { Obtained }\end{array}$ \\
\hline lst & 1 & $\mathrm{a}$ & 3 \\
\hline 2nd & a & 1 & 3 \\
\hline $3 \mathrm{rd}$ & 2 & b & 2 \\
\hline 4th & a & b & 3 \\
\hline
\end{tabular}

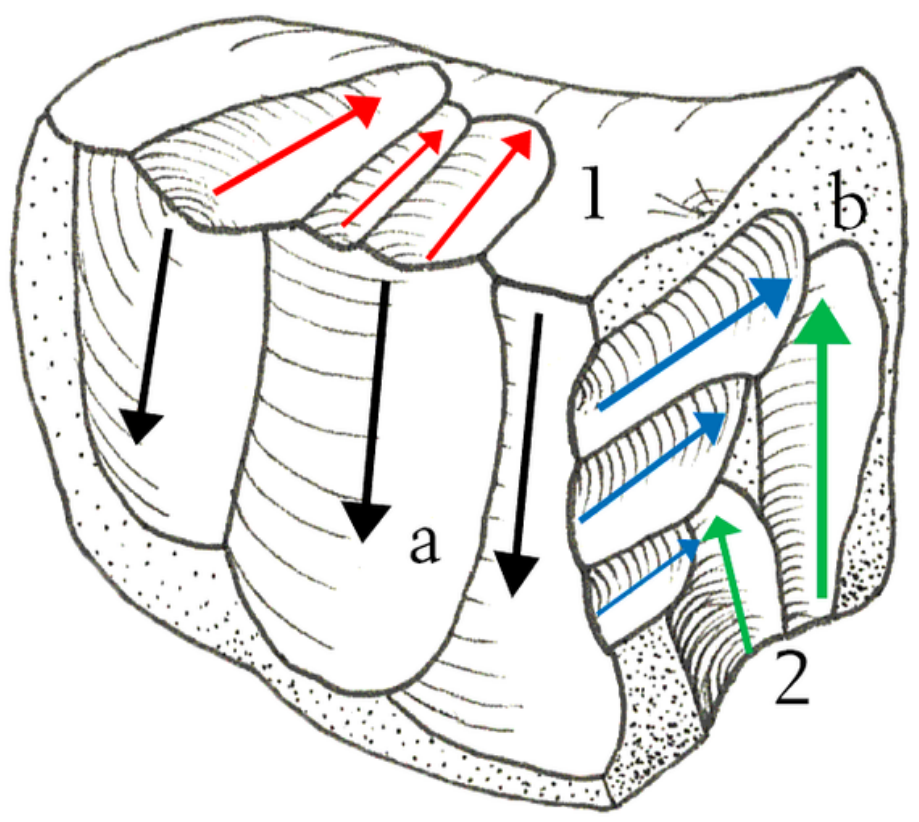

\section{Figure 2}

Experimental protocol: example of an experimental core with its relative operative scheme. The arrows' colours are related to their respective knapping event. Each arrow indicates a removal and its direction. 


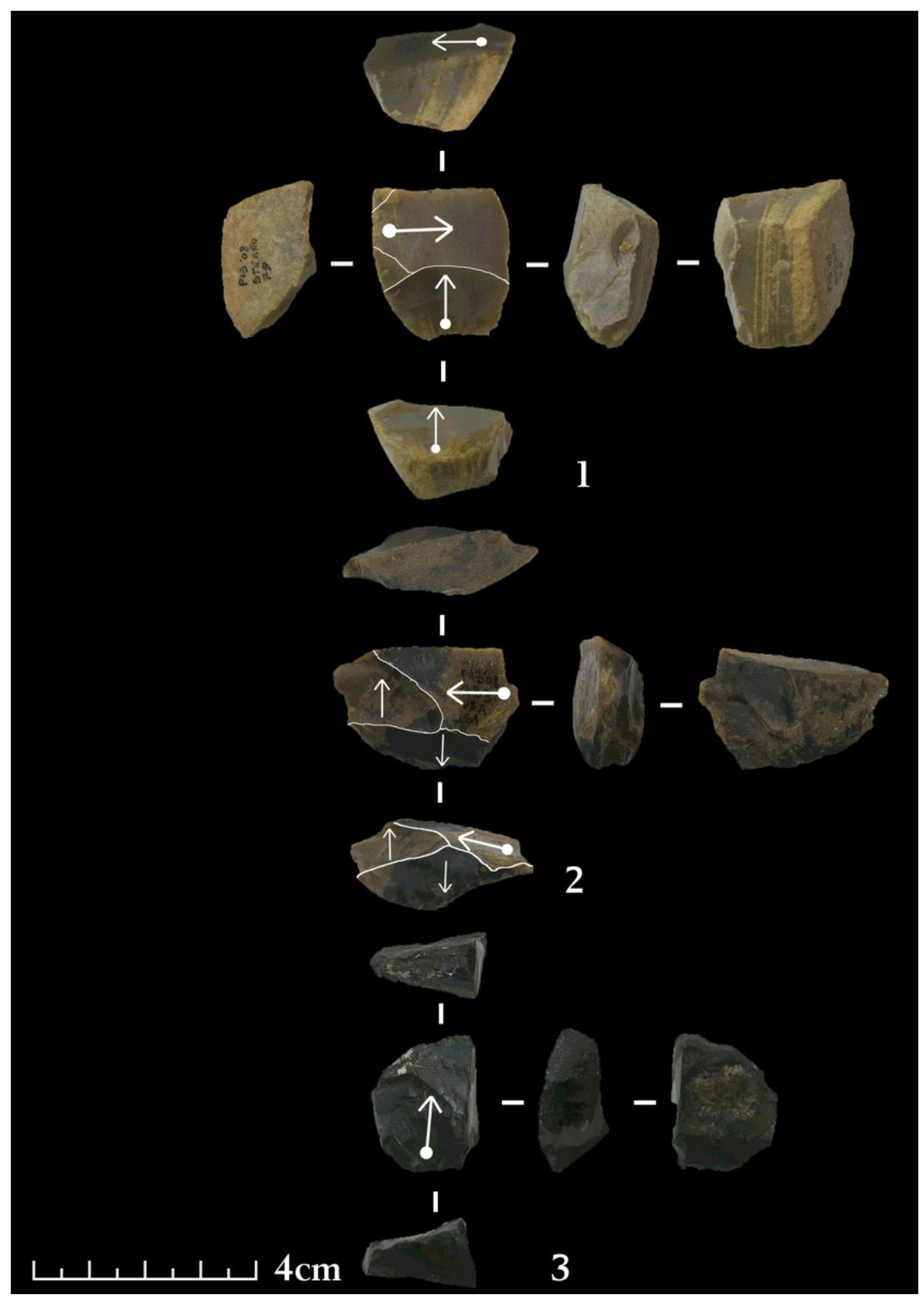

\section{Figure 3}

Pirro Nord, archaeological. 1: orthogonal core; 2: multifacial orthogonal core on flake; 3: unipolar core. 


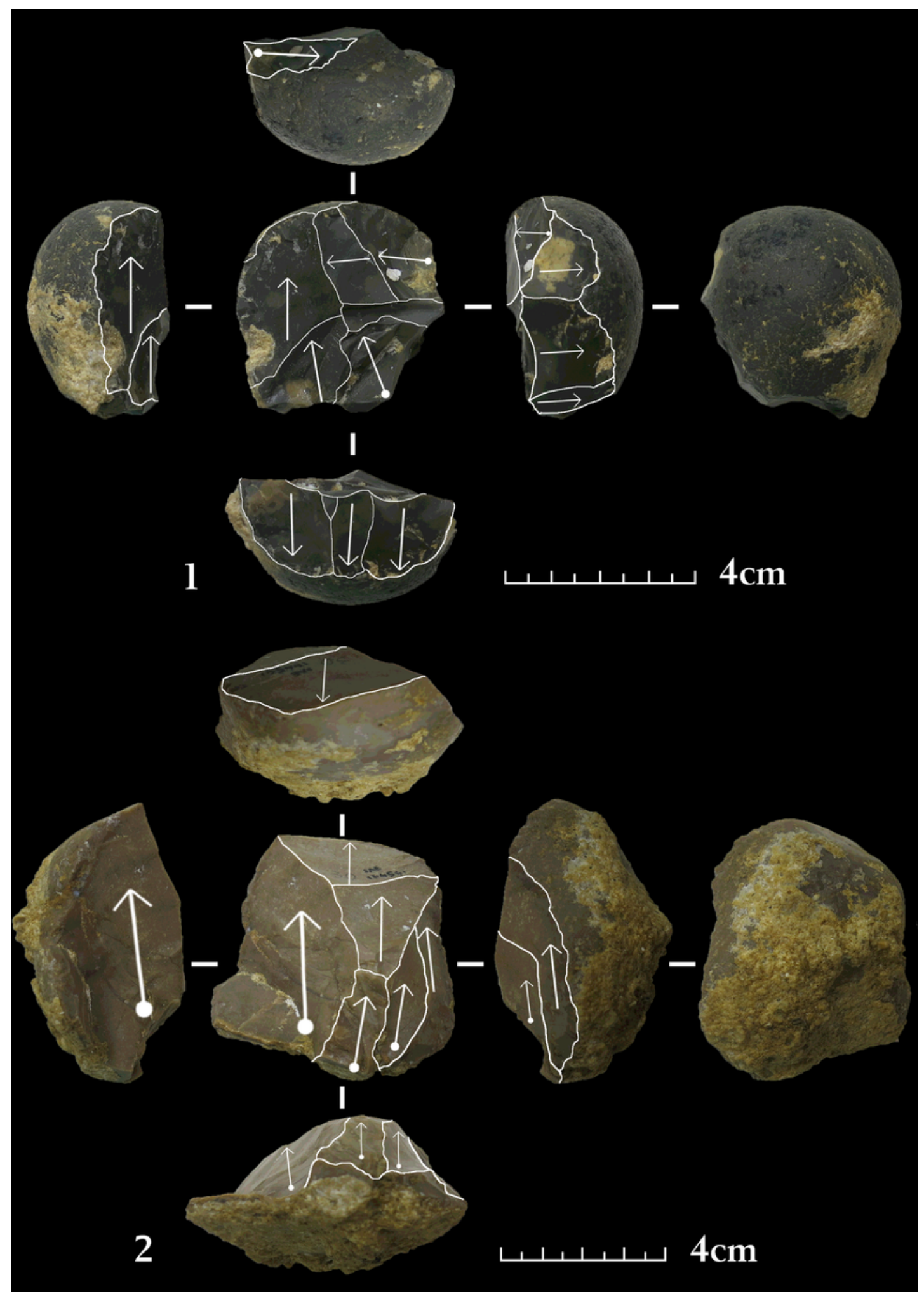

Figure 4

Cà Belvedere di Montepoggiolo, archaeological. 1: orthogonal multifacial core on small pebble; 2: unipolar core on large pebble. 
Archaeological Flakes Length/Width ratio

4

$$
n=67
$$

-

$n=62$

3

3.
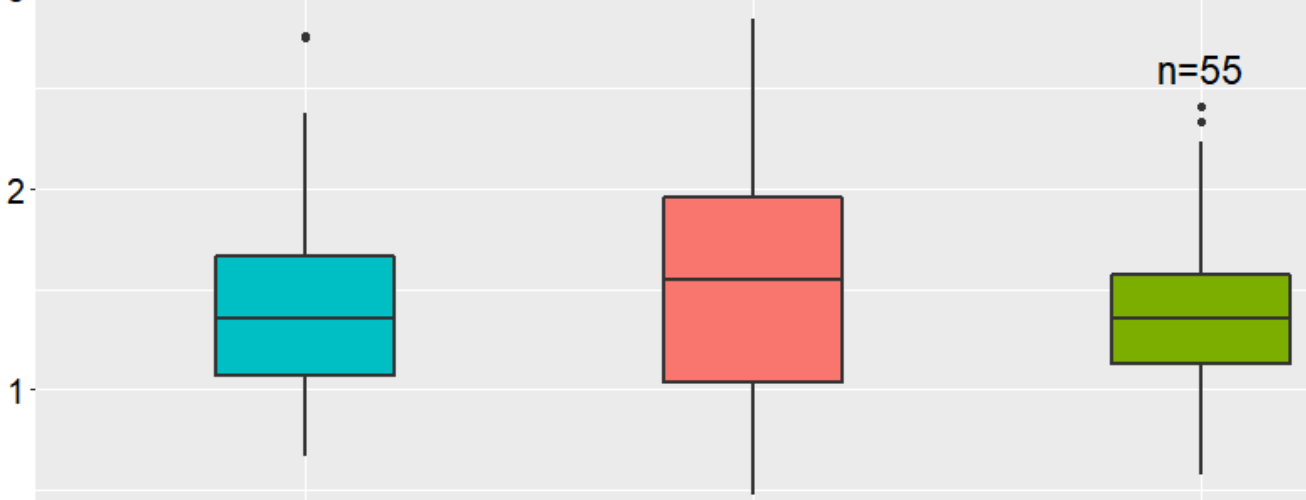

0

Pirro Nord

Cà Belvedere di Montepoggiolo

Ciota Ciara cave

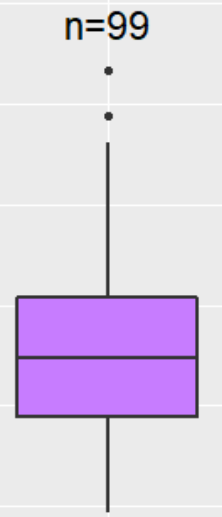

Figure 5

Dimensional variability of archaeological flakes; $y$ axe: length/width ratio; $x$ axe: archaeological site. 


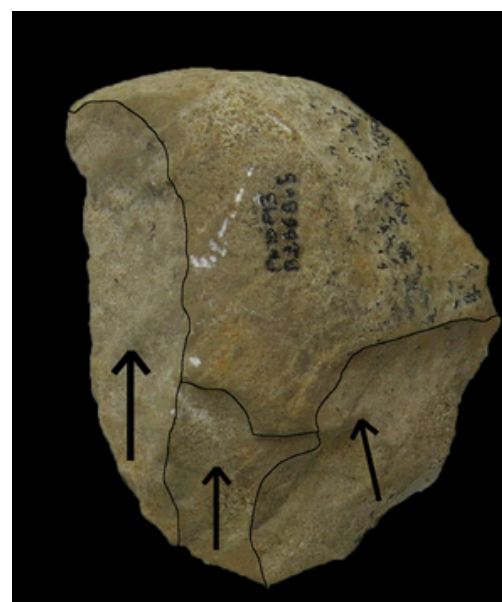

1

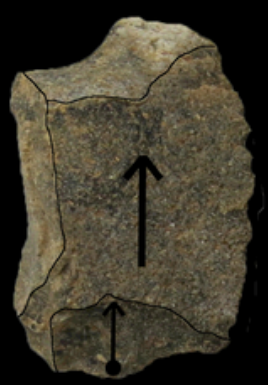

2

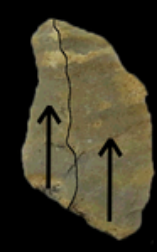

3
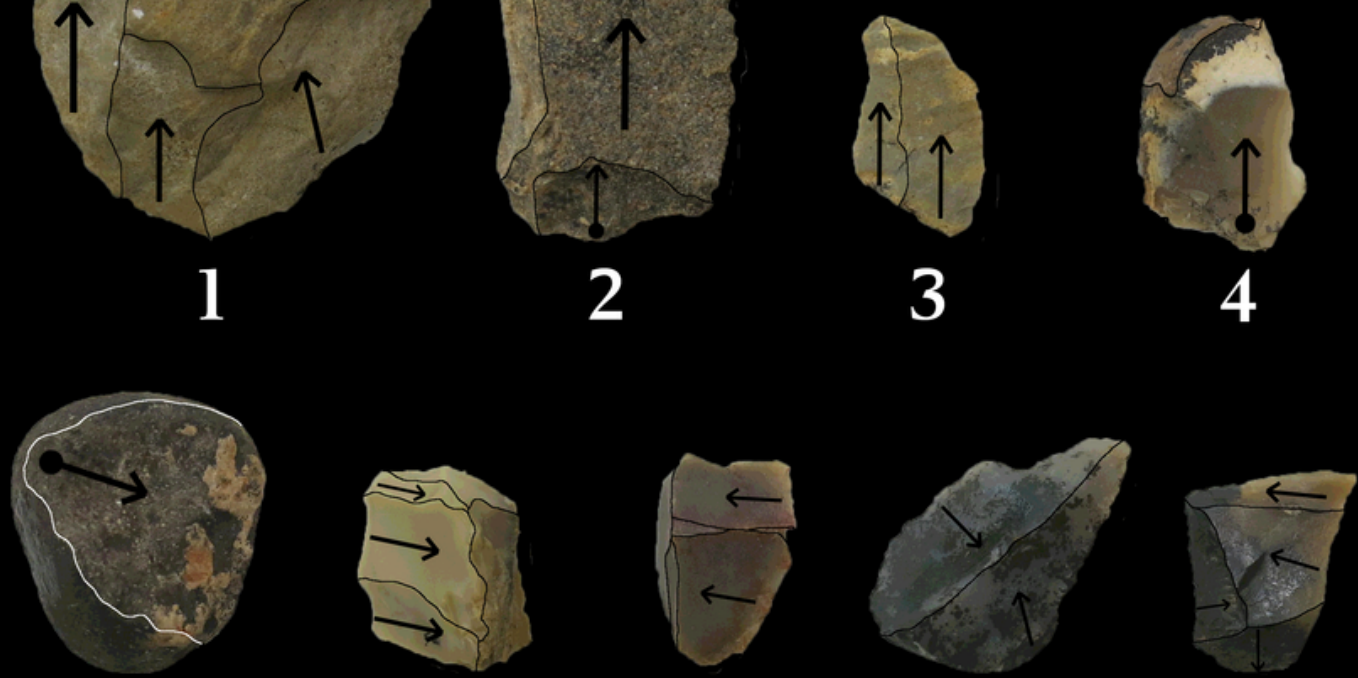

5

6

7

8

9

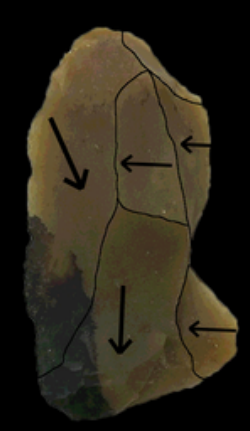

10

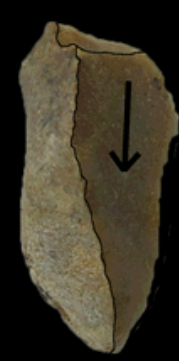

11

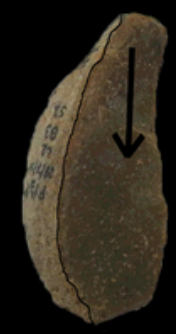

12

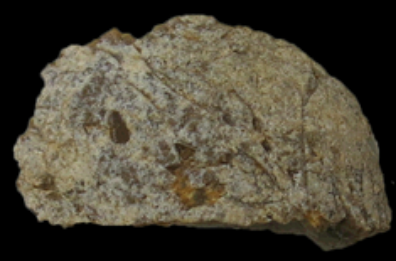

13

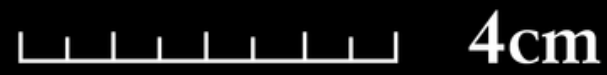

\section{Figure 6}

Pirro Nord, archaeological. 1-4: flakes with unipolar scars; 5-7: flakes with orthogonal scars; 8-10: flakes with centripetal scars; 11-12: flakes with bipolar scars; 13: cortical flake. 


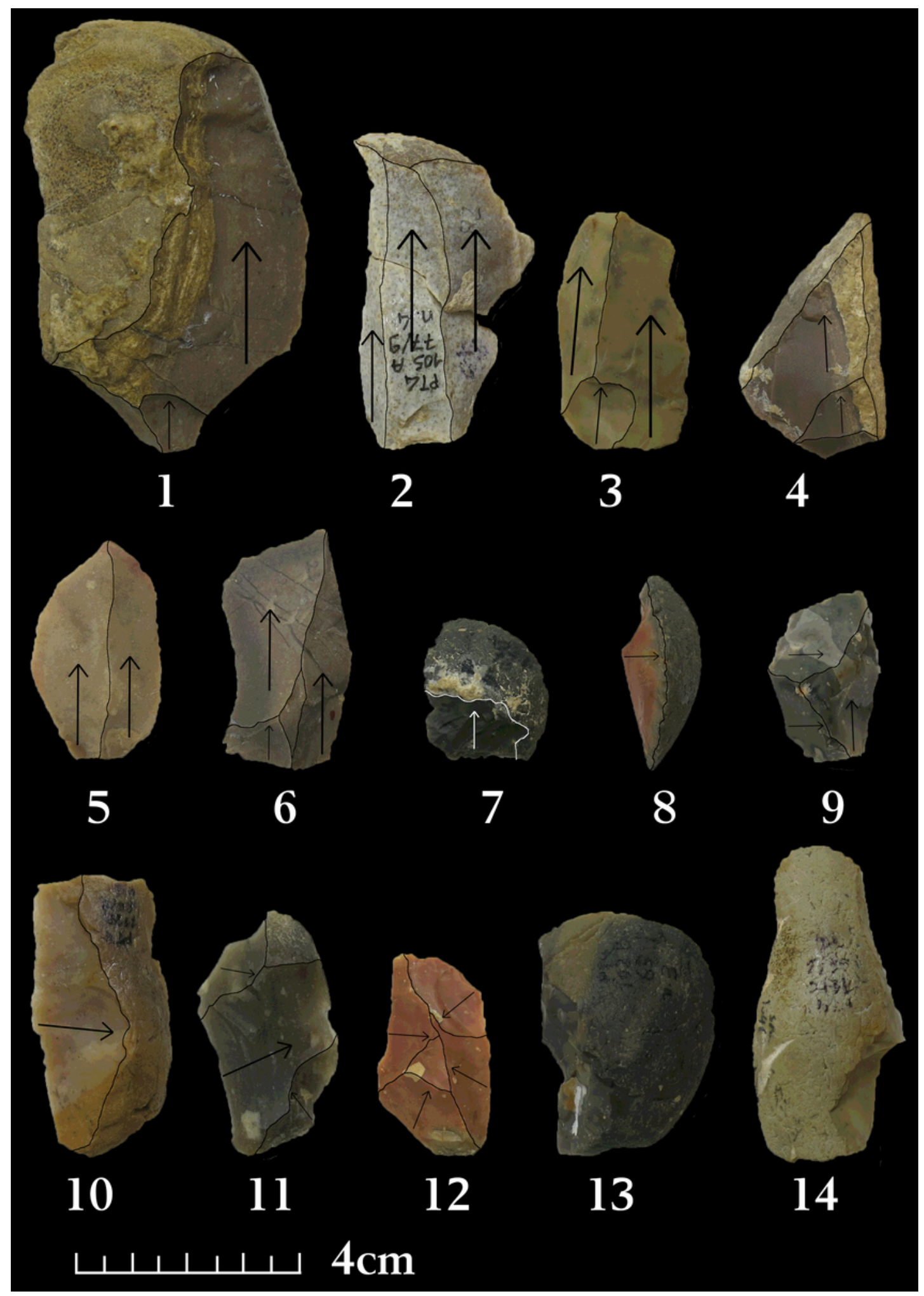

\section{Figure 7}

Cà Belvedere di Montepoggiolo, archaeological. 1-7: flakes with unipolar scars; 8-10: flakes with orthogonal scars; 11-12: flakes with centripetal scars; 13-14: cortical flakes. 


\section{Cortex}

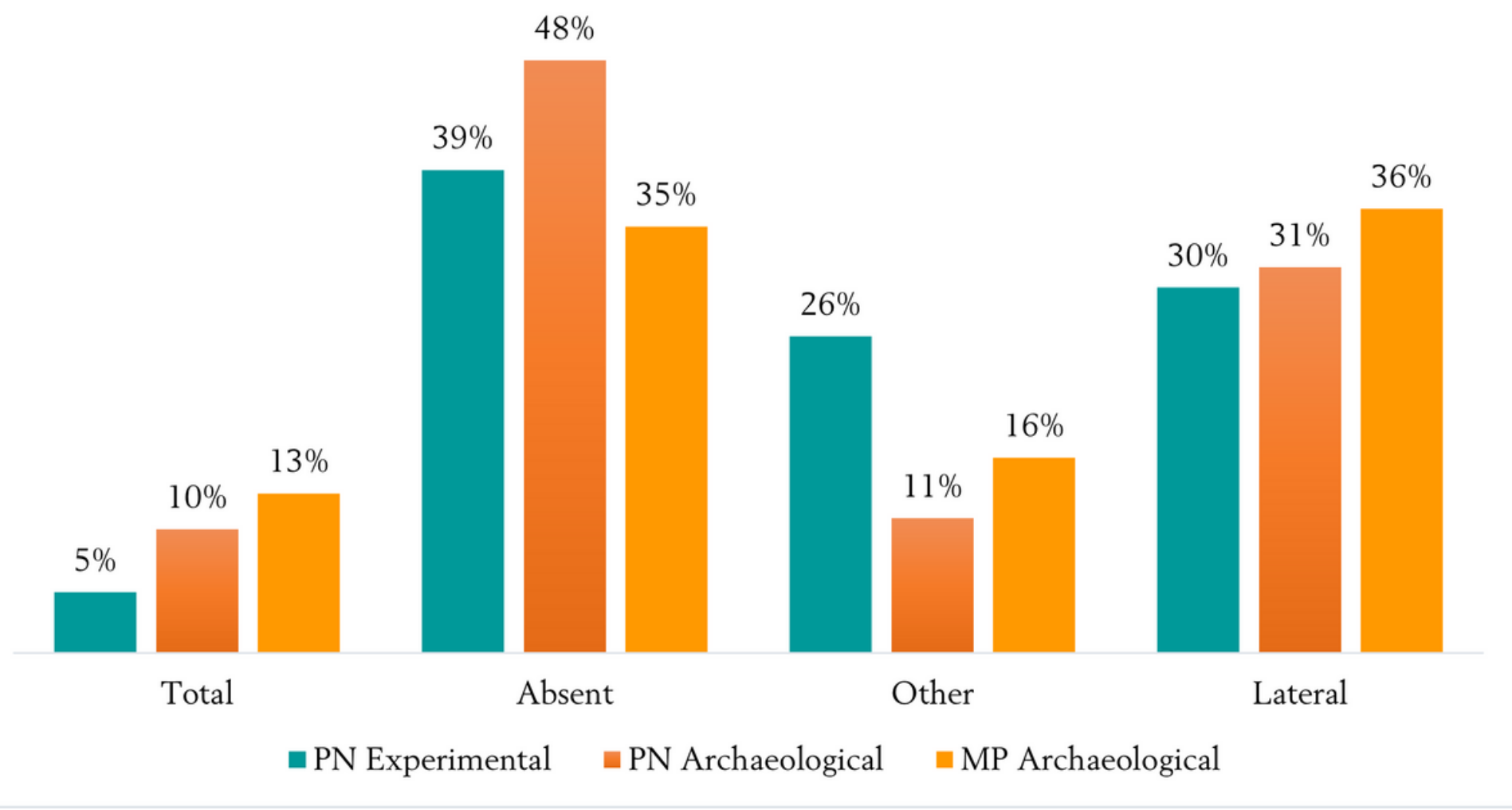

Figure 8

Pirro Nord and Cà Belvedere di Montepoggiolo. Presence and position of cortex on archaeological and experimental flakes from Pirro Nord (PN) and archaeological flakes from Cà Belvedere di Montepoggiolo (MP). 


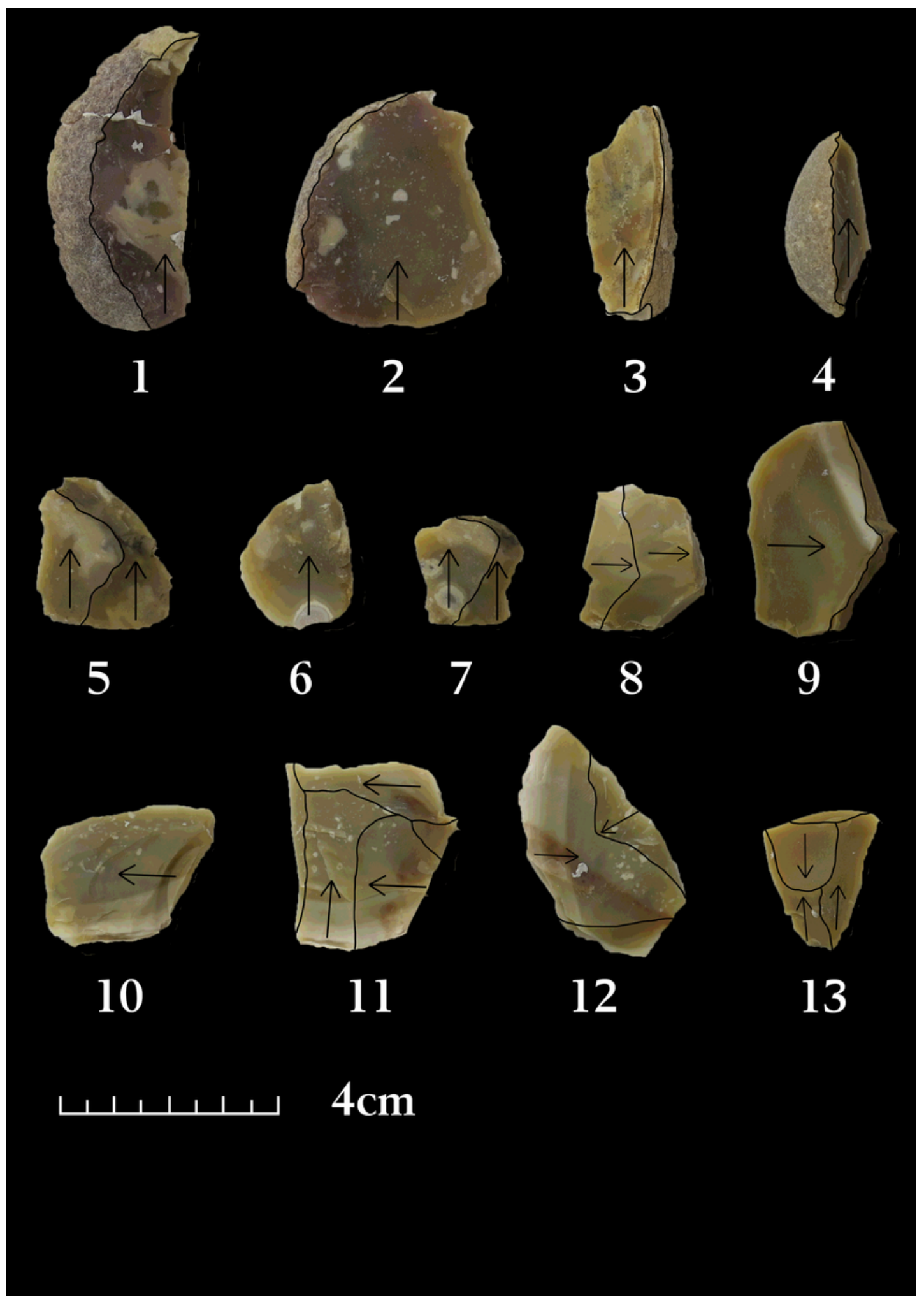

\section{Figure 9}

Pirro Nord, experimental. 1-7: flakes with unipolar scars; 8-11 flakes with orthogonal scars; 12: flake with centripetal scars; 13: flake with bipolar scar. 


\section{Debordant and Plunging flakes}

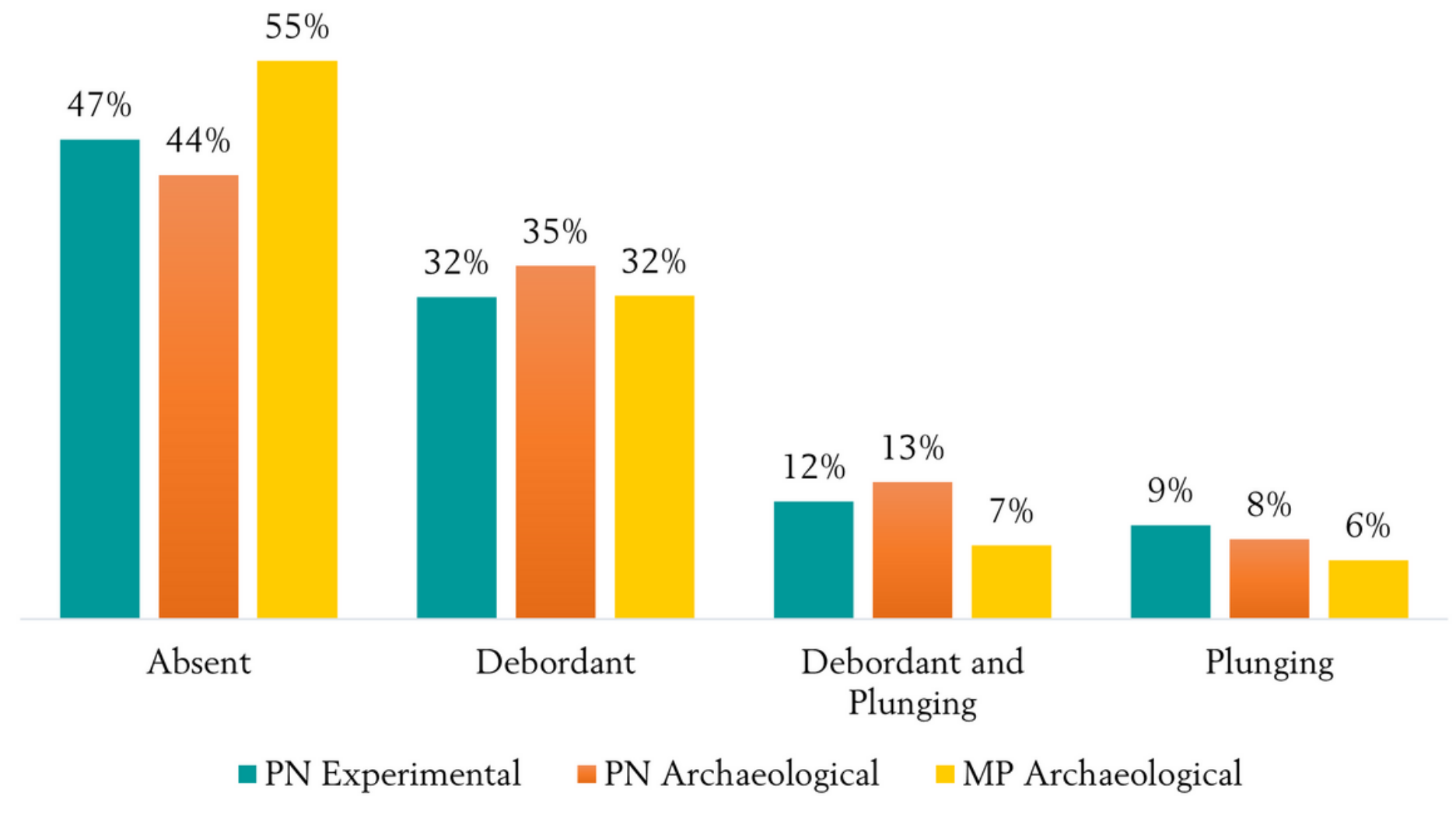

Figure 10

Pirro Nord and Cà Belvedere di Montepoggiolo. Distribution of debordant and plunging flakes on archaeological and experimental collections from Pirro Nord (PN) and archaeological flakes from Cà Belvedere di Montepoggiolo (MP). 


\section{Flakes' Removals}

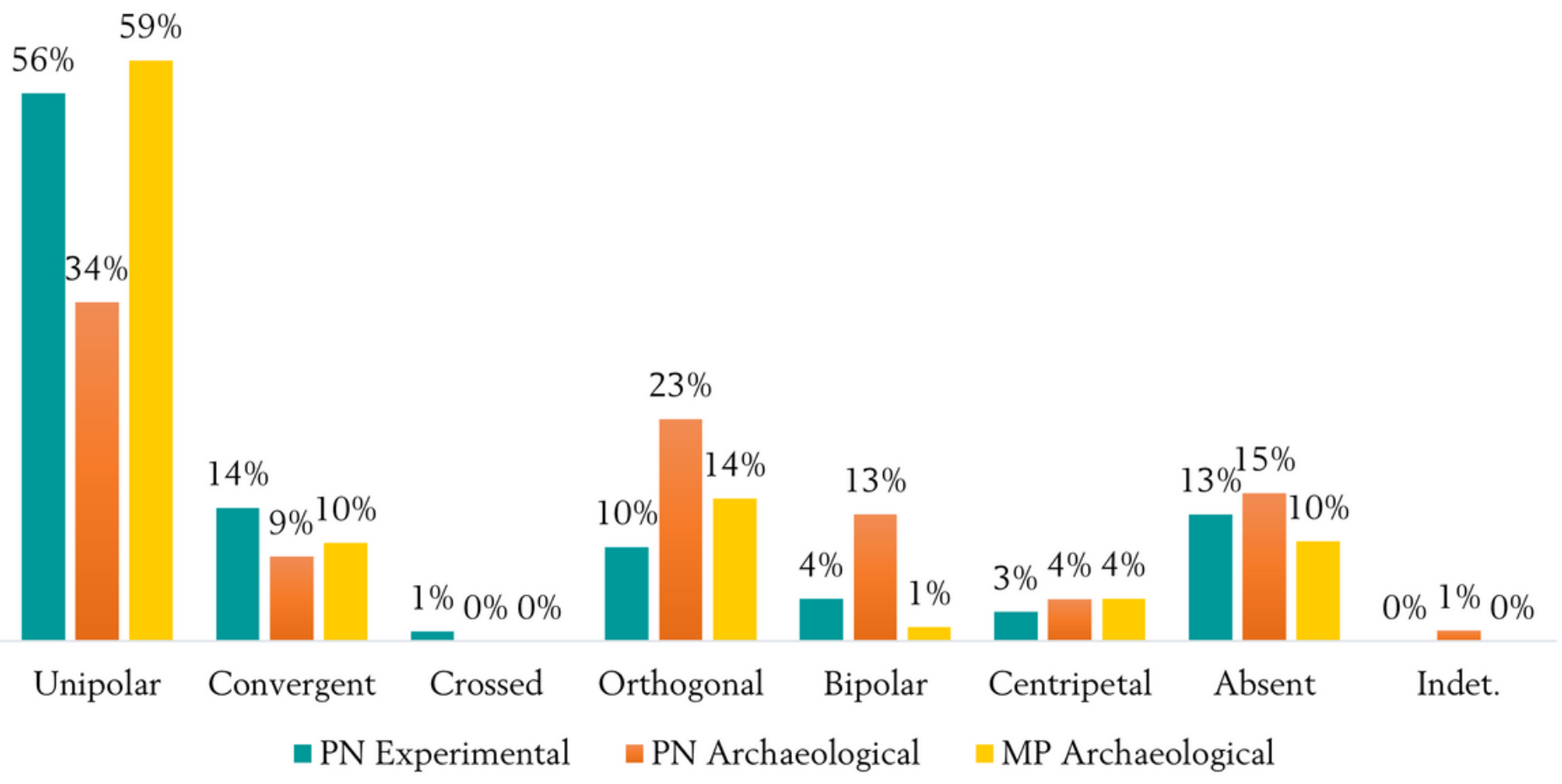

\section{Figure 11}

Pirro Nord and Cà Belvedere di Montepoggiolo. Presence and position of removals on archaeological and experimental flakes from Pirro Nord (PN) and archaeological flakes from Cà Belvedere di Montepoggiolo (MP). 


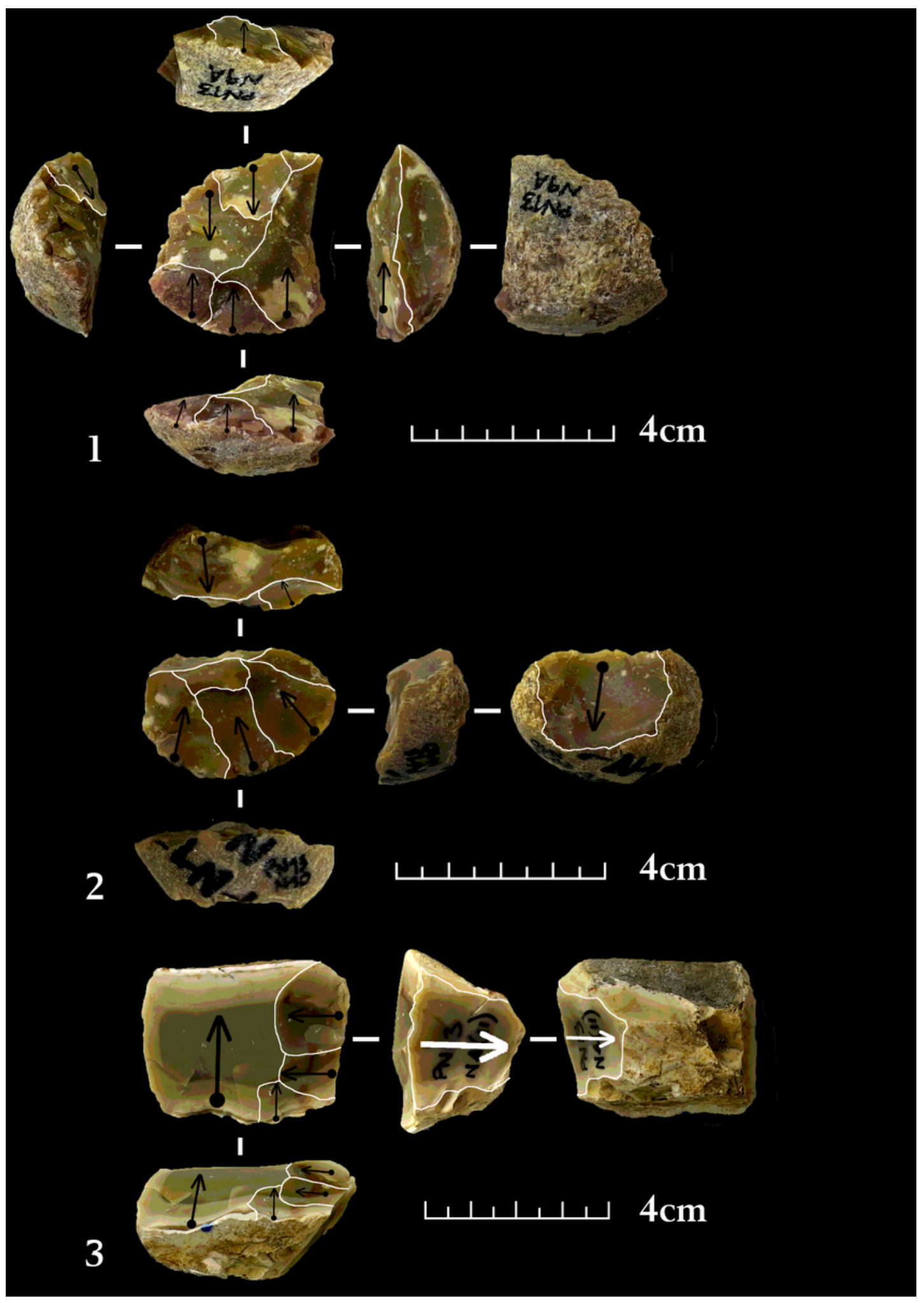

Figure 12

Pirro Nord, experimental. 1 - bipolar core on small pebble open by split fracture; 2 - unipolar multifacial core on small pebble open by split fracture; 3 orthogonal multifacial core. 


\section{Flakes' Removals}

$66 \%$

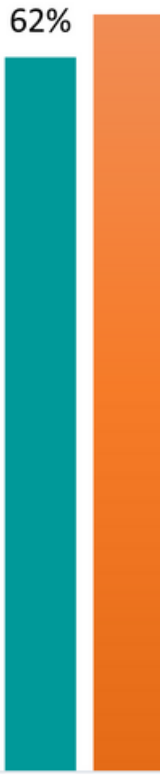

Unipolar

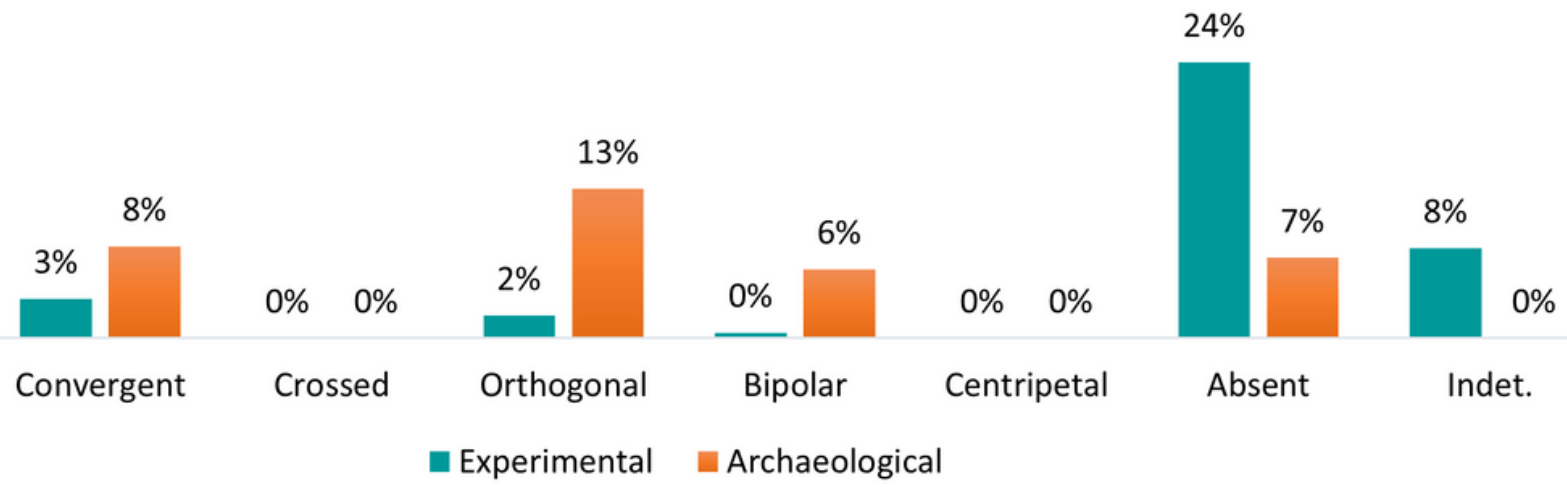

Figure 13

Ciota Ciara cave. Presence and position of removals on archaeological and experimental flakes. 


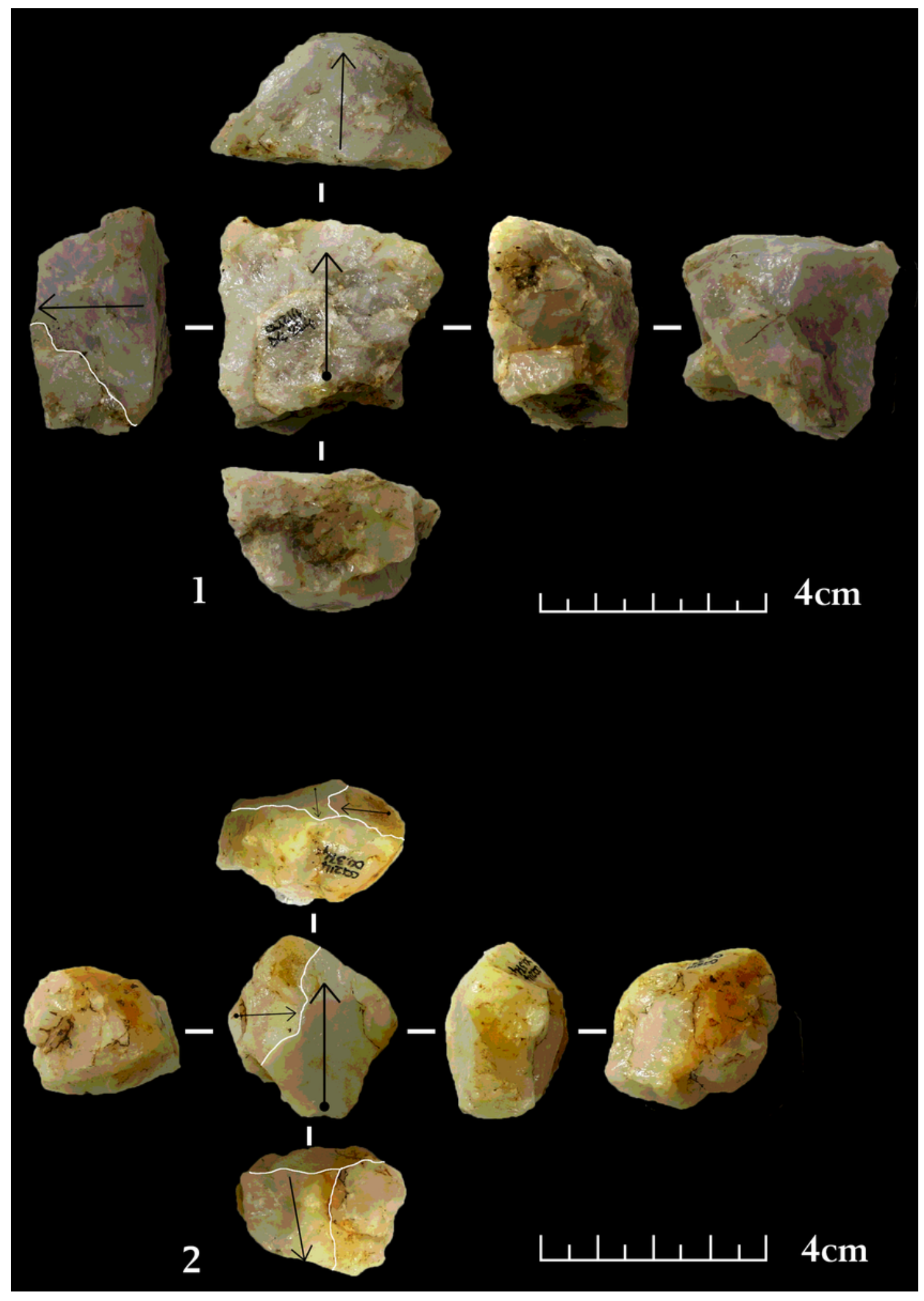

Figure 14

Ciota Ciara cave, archaeological. 1 - unipolar multifacial core; 2 - orthogonal multifacial core. 


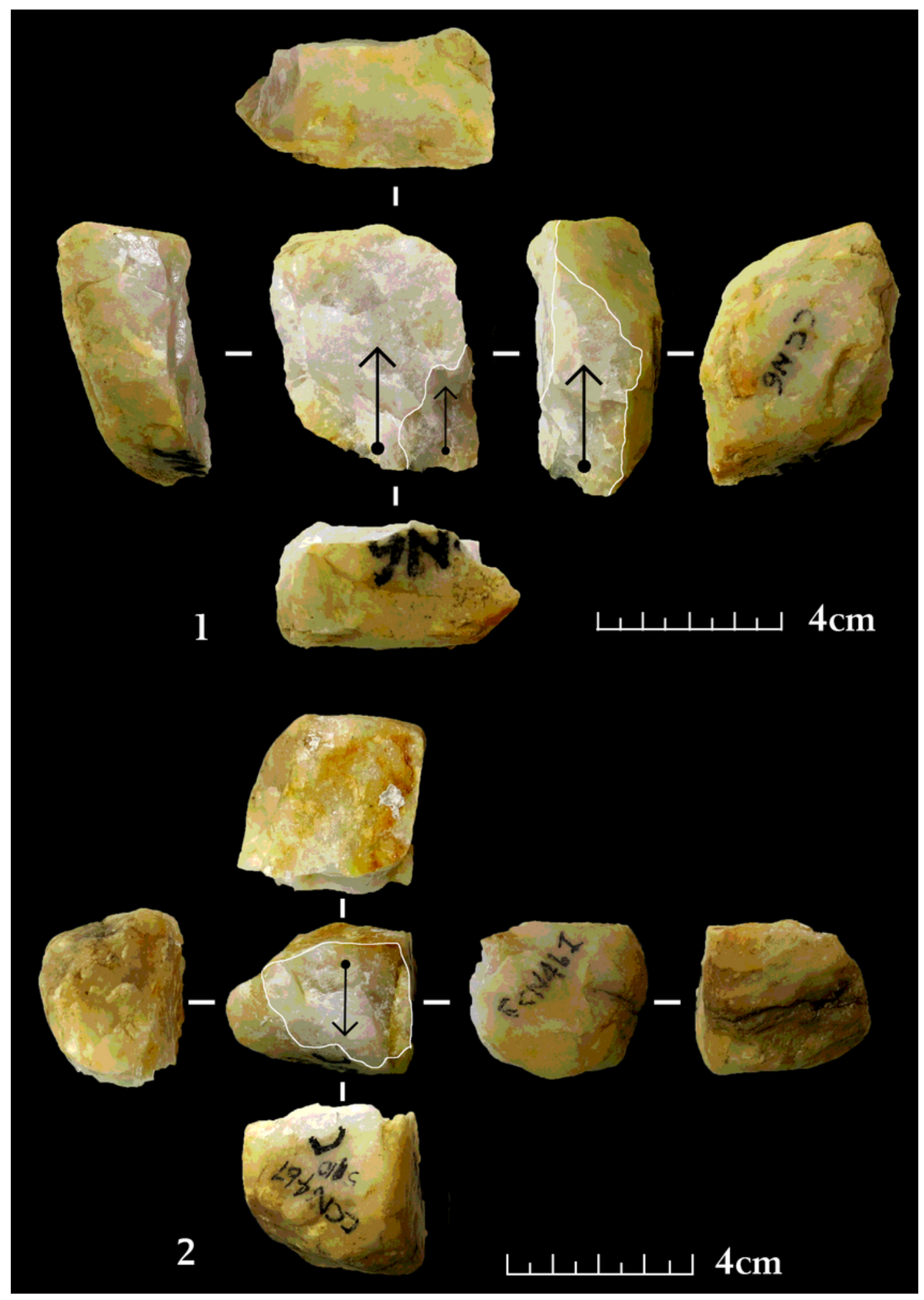

Figure 15

Ciota Ciara cave, experimental. 1: unipolar multifacial core; 2: unipolar core. 


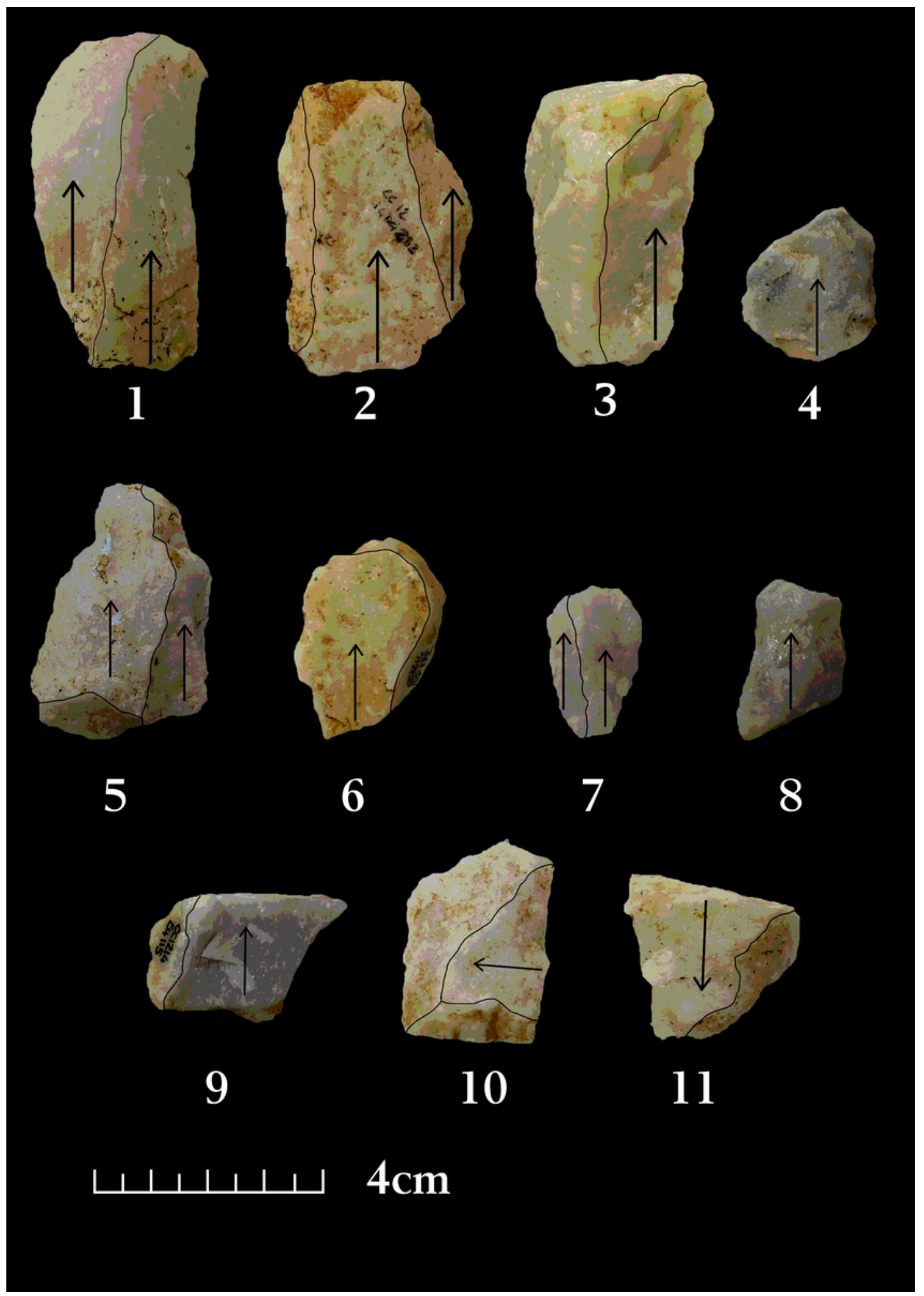

Figure 16

Ciota Ciara cave, archaeological. 1-9: flakes with unipolar scars; 10: flake with orthogonal scars: 11: flake with bipolar scars. 


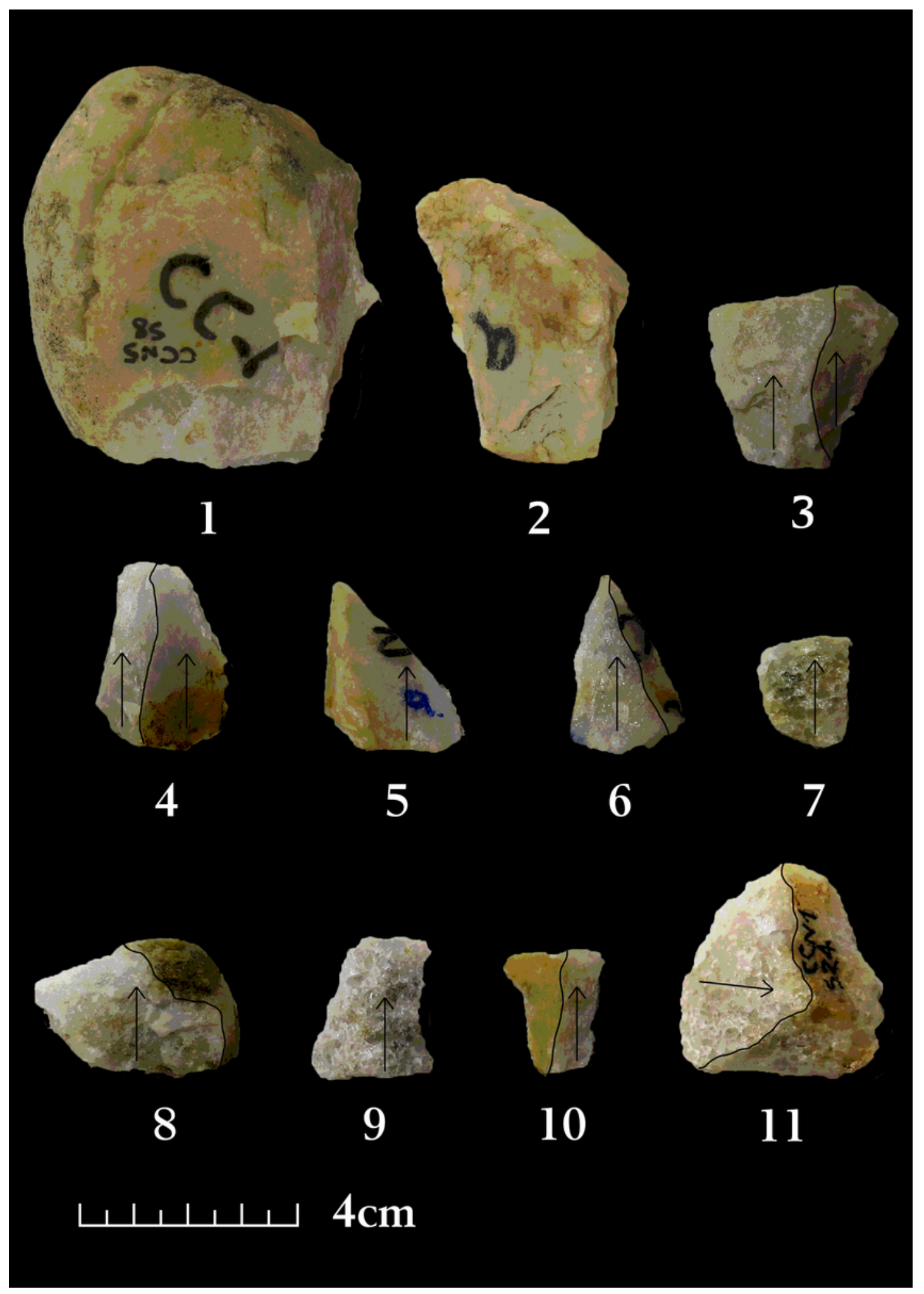

\section{Figure 17}

Ciota Ciara cave, experimental. 1-2: cortical flakes; 3-10: flakes with unipolar scars; 11: flake with orthogonal scars. 


\section{Debordant and Plunging}

\section{$62 \%$}

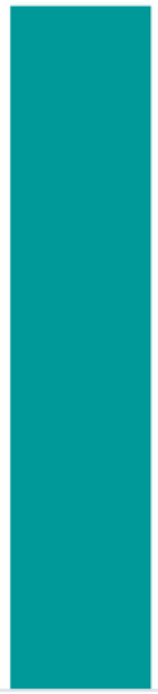

$47 \%$

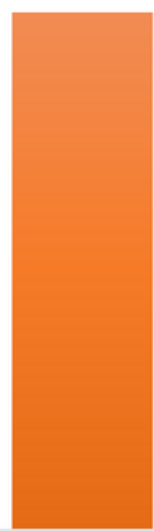

$27 \%$

Absent

Debordant

Debordant and

Plunging

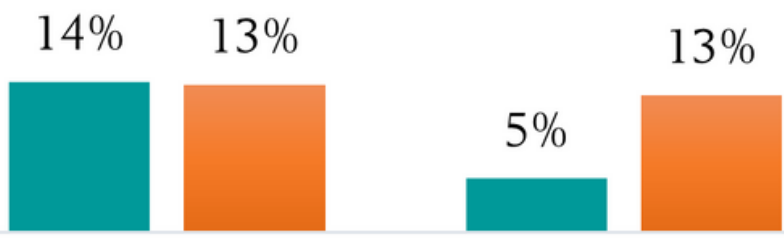

Plunging
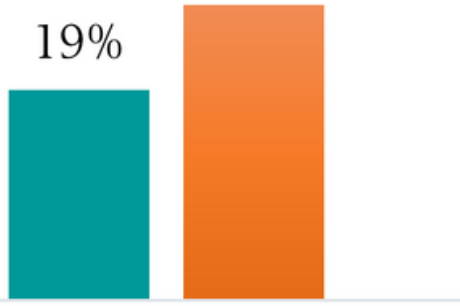

rchaeological

\section{Figure 18}

Ciota Ciara cave. Distribution of debordant and plunging flakes on archaeological and experimental collections. 


\section{Cortex}

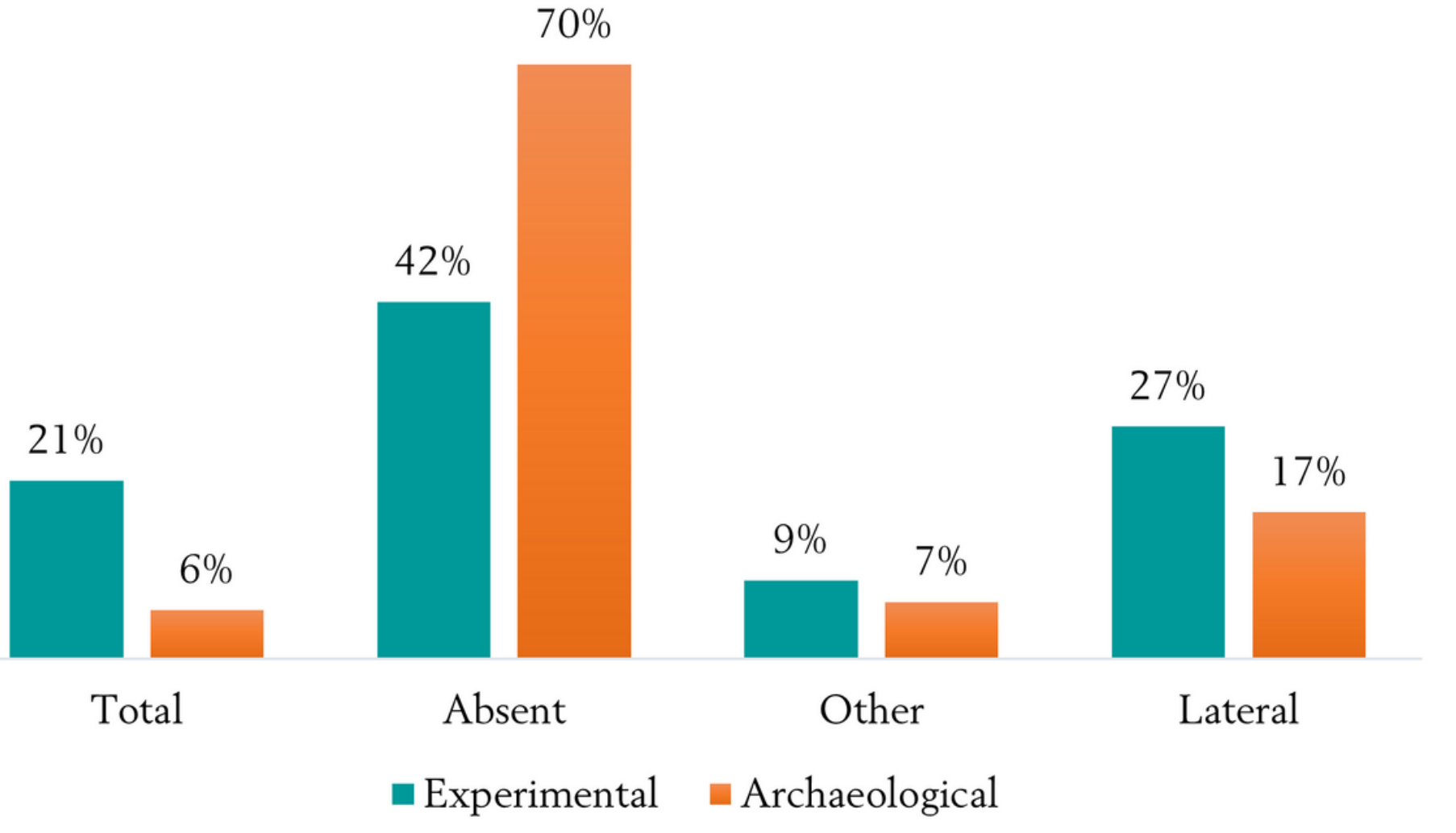

Figure 19

Ciota Ciara cave. Presence and position of cortex on archaeological and experimental flakes. 


\section{Debordant and Plunging}

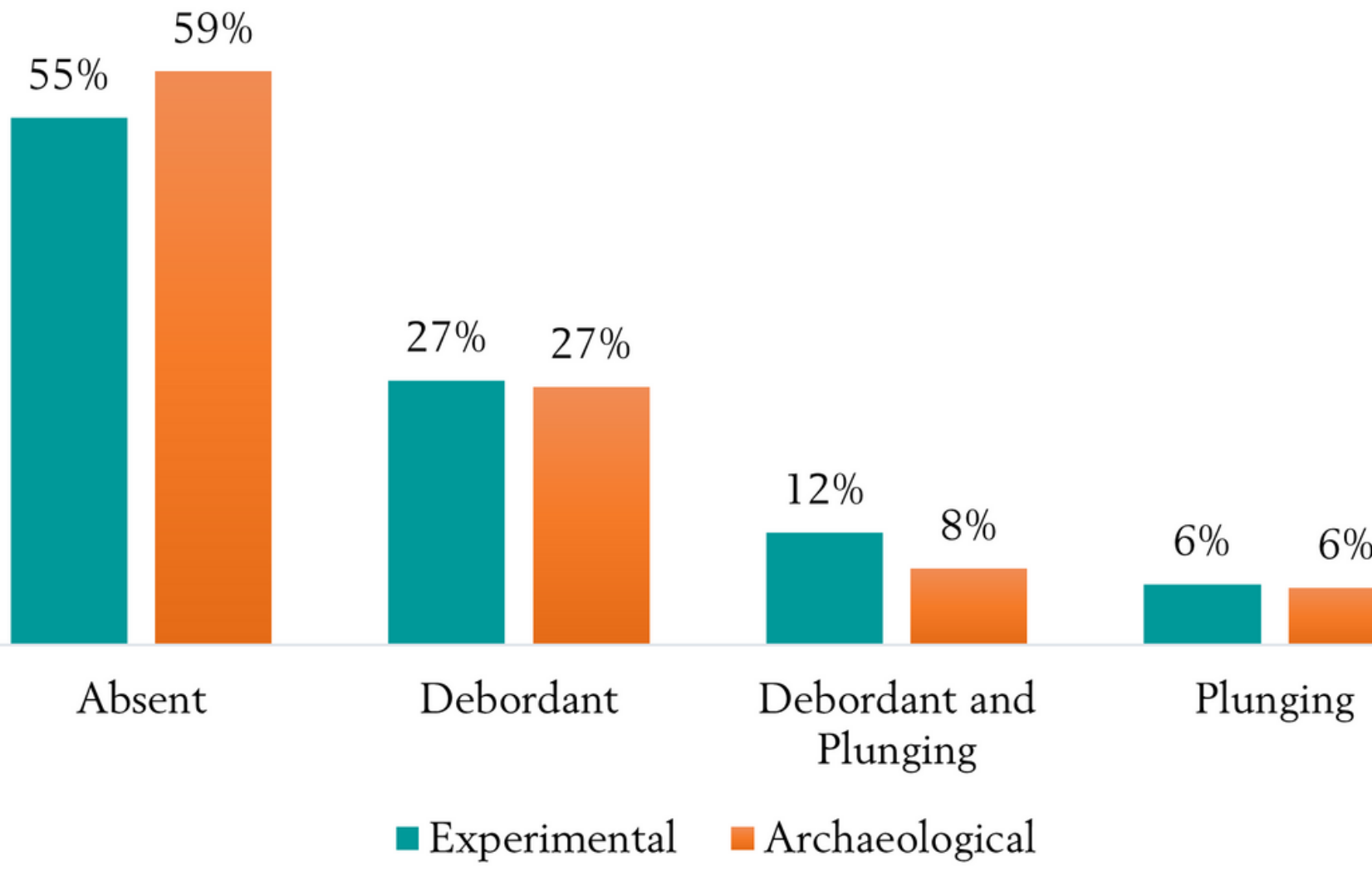

Figure 20

Riparo Tagliente. Distribution of debordant and plunging flakes on archaeological and experimental collections. 


\section{Cortex}

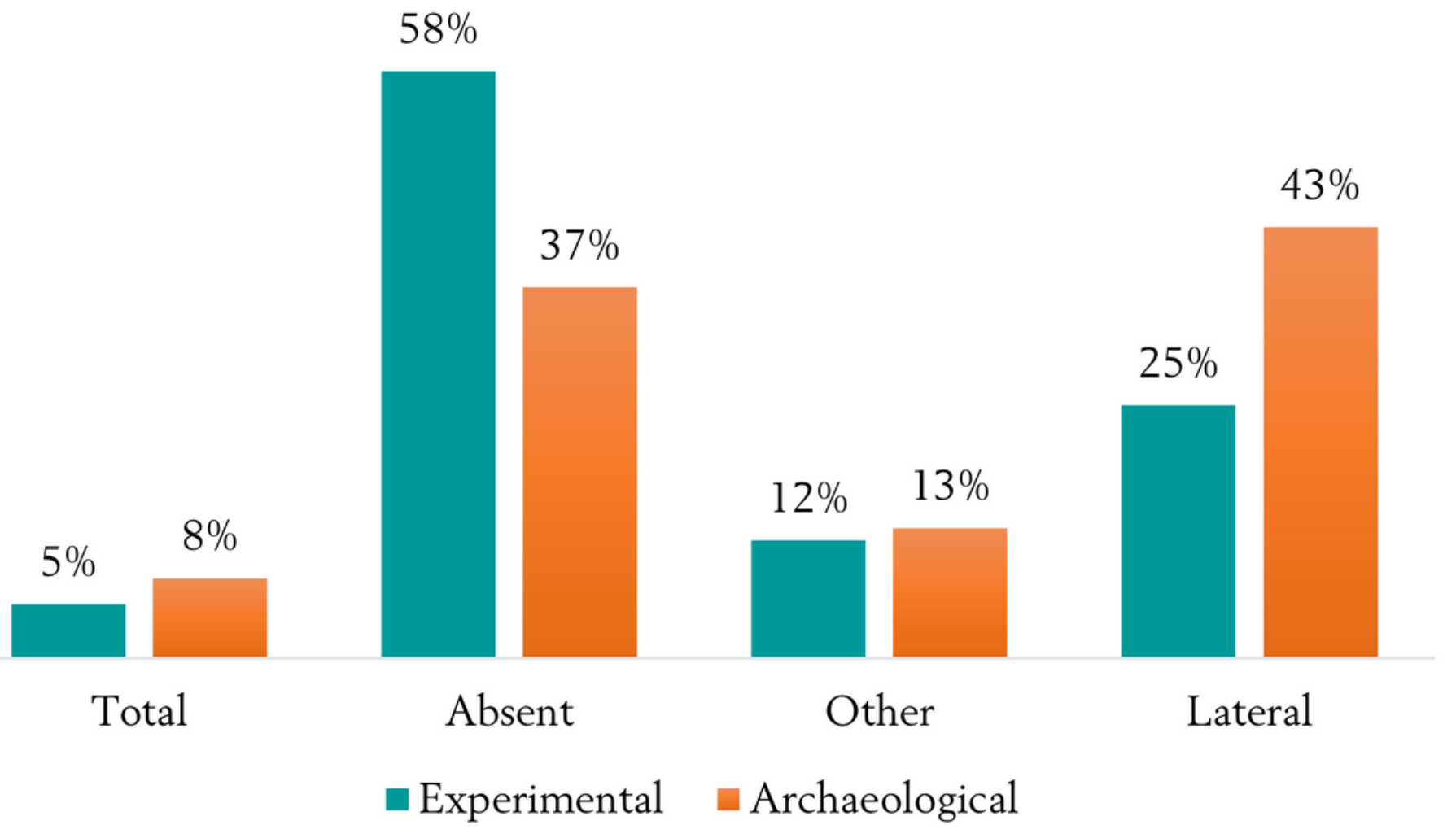

Figure 21

Riparo Tagliente. Presence and position of cortex on archaeological and experimental flakes. 


\section{Flakes' Removals}
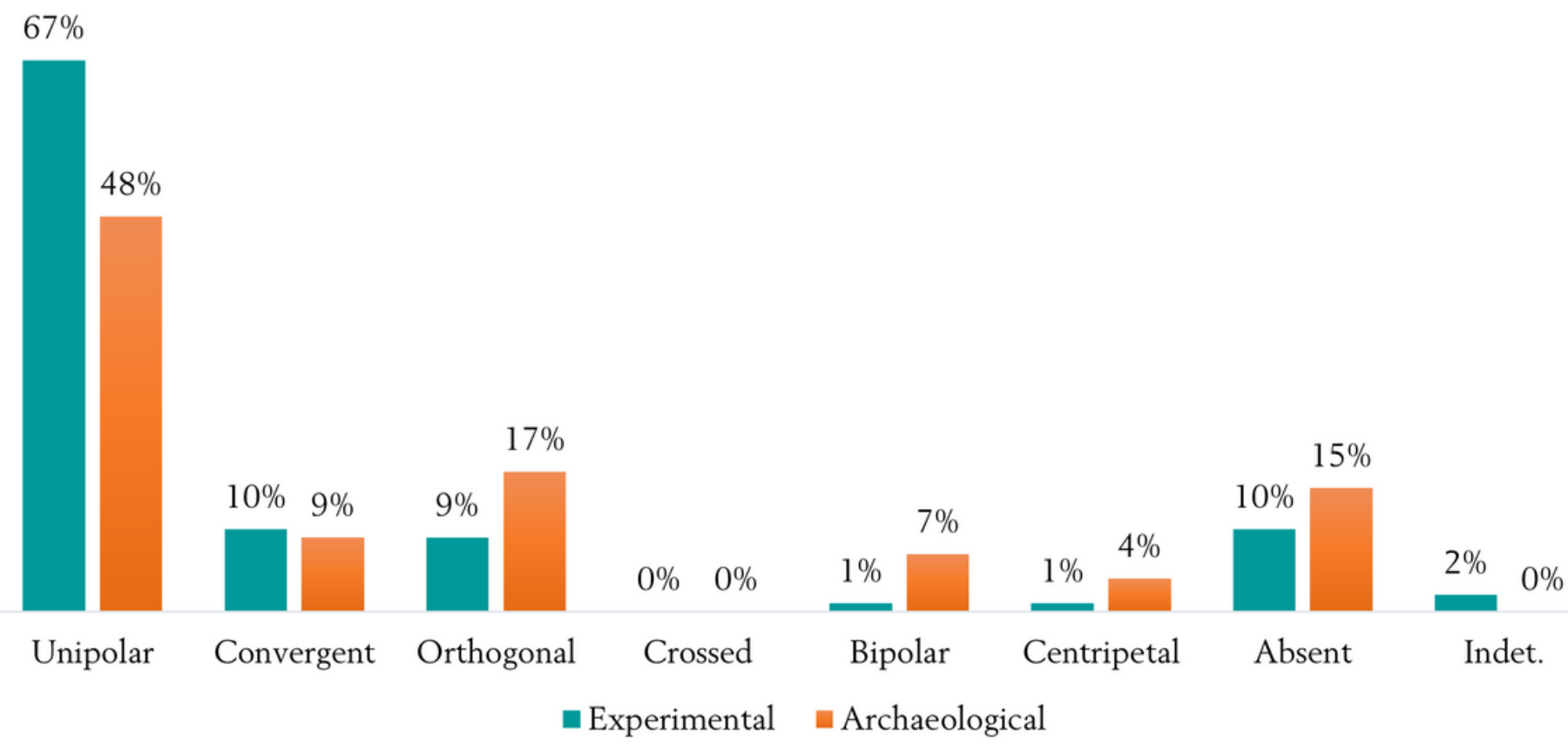

Figure 22

Riparo Tagliente. Presence and position of removals on archaeological and experimental flakes. 


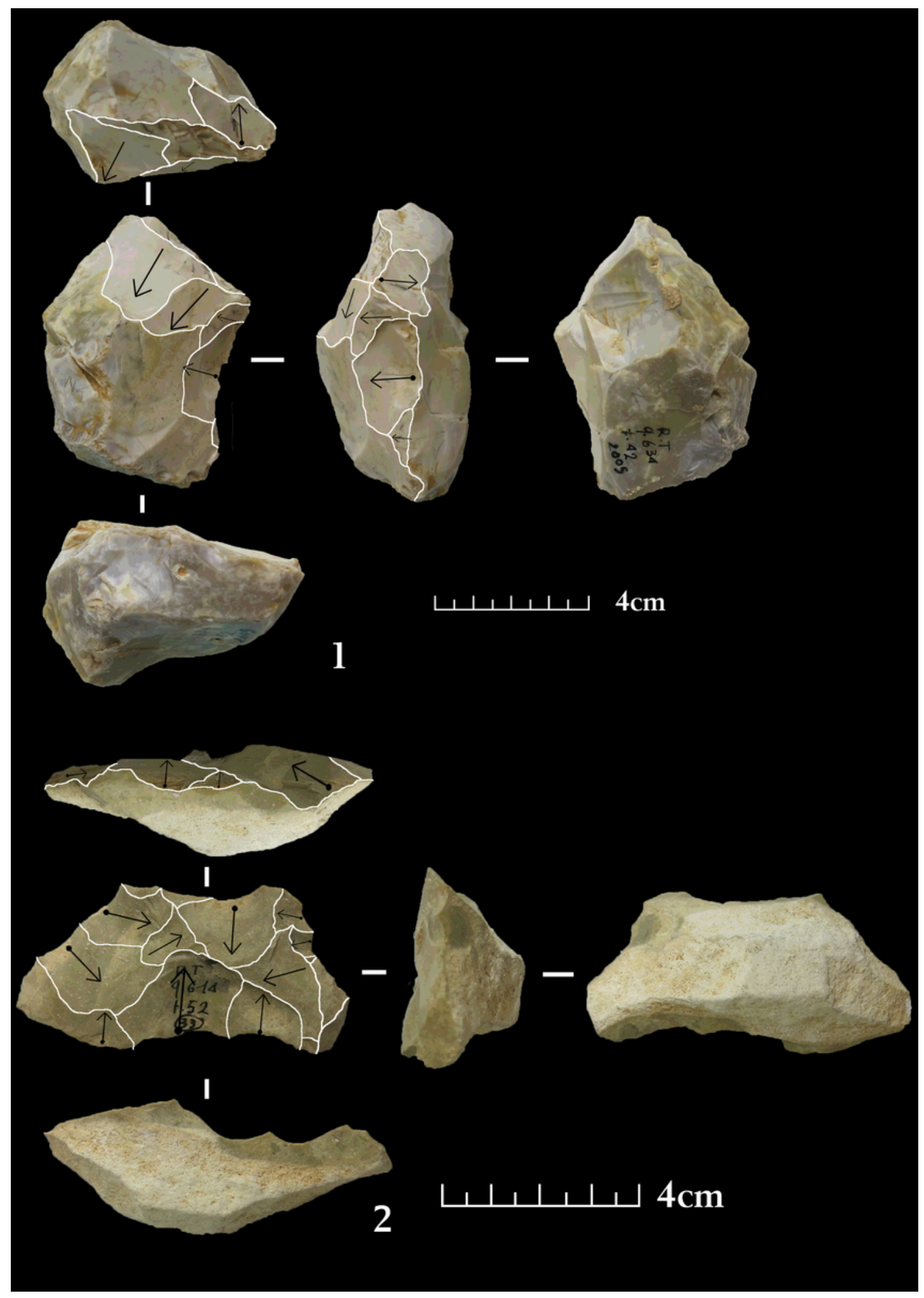

Figure 23

Riparo Tagliente, archaeological. 1 - multifacial unipolar core; 2 - centripetal core. 


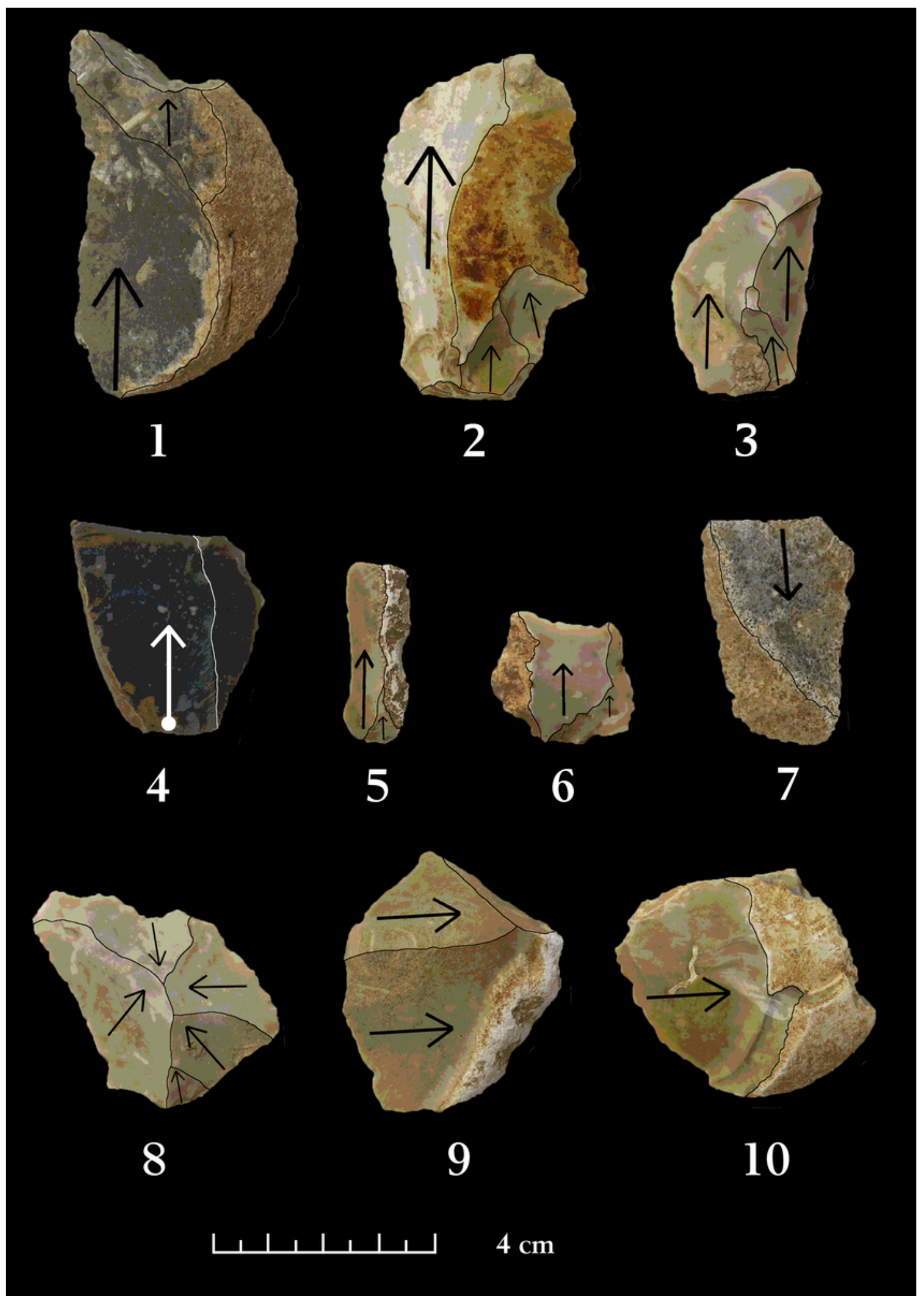

\section{Figure 24}

Riparo Tagliente, archaeological.1-6: flakes with unipolar scars; 7: flake with bipolar scars; 8: flake with centripetal scars; 9-10: flakes with orthogonal scars. 


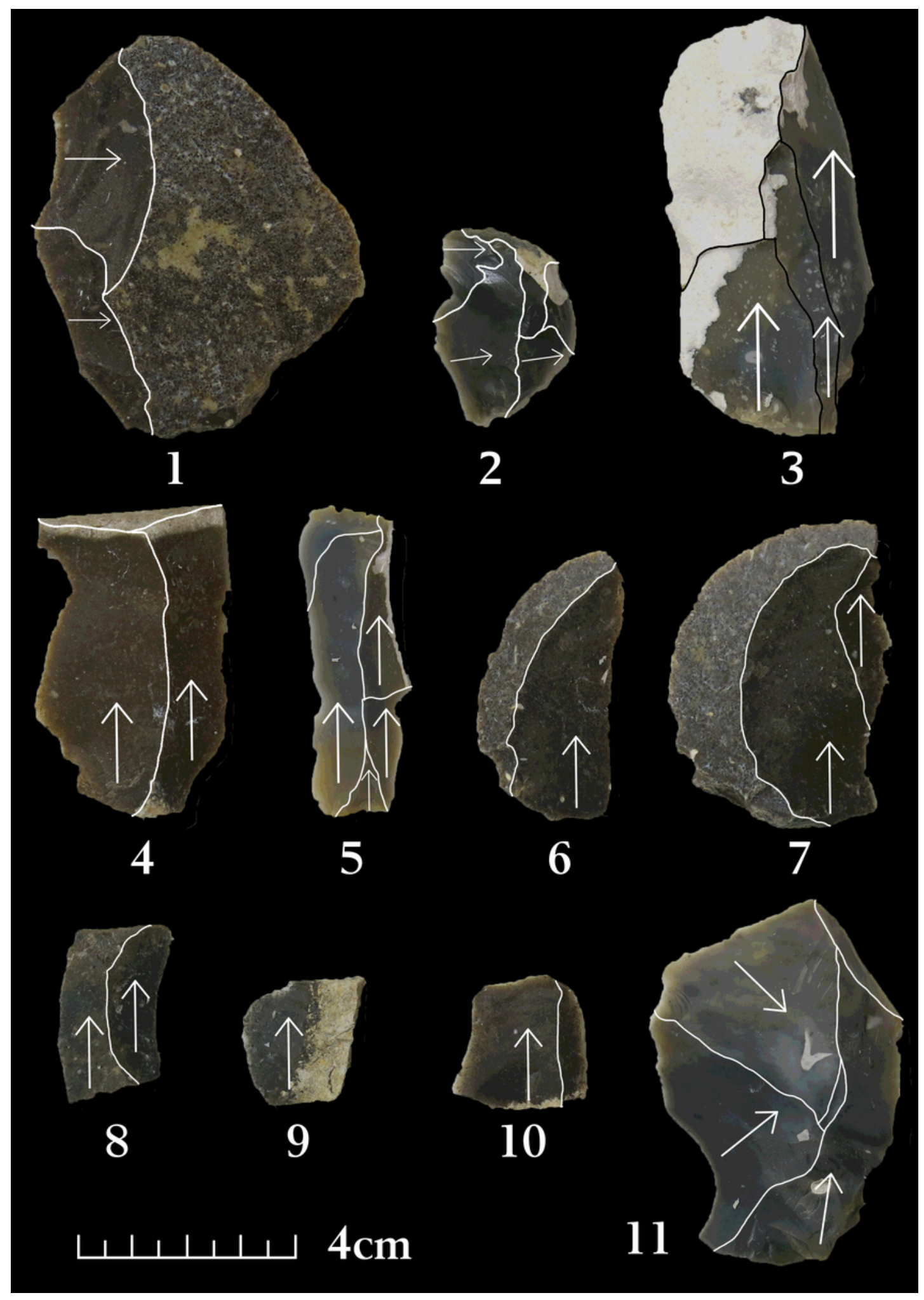

\section{Figure 25}

Riparo Tagliente, experimental. 1-2: flakes with orthogonal scars; 3-10: flakes with unipolar scars; 11: flake with centripetal scars. 


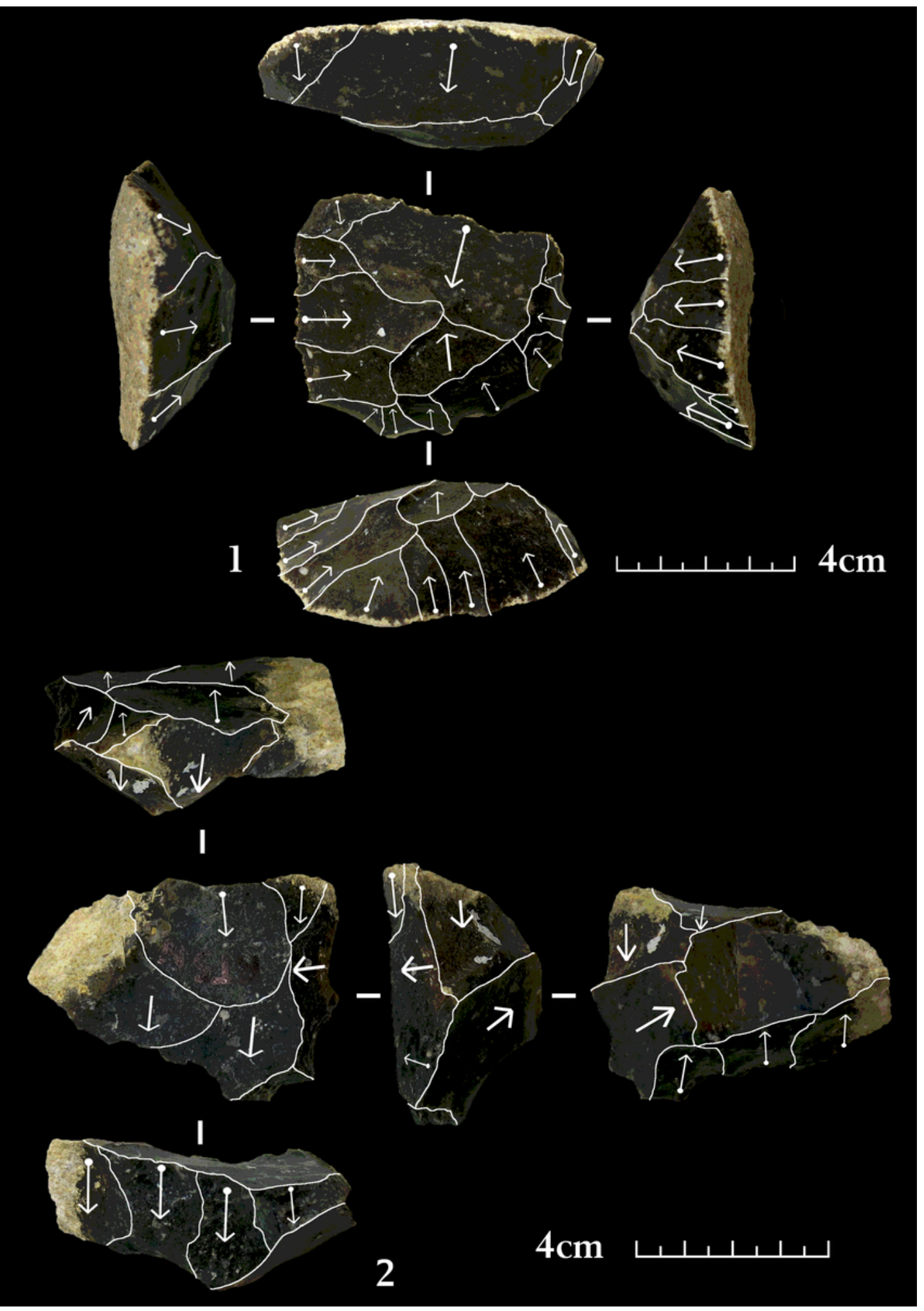

Figure 26

Riparo Tagliente, experimental. 1 - centripetal core; 2 - multifacial core.

\section{Supplementary Files}

This is a list of supplementary files associated with this preprint. Click to download. 
- CarpentieriandArzarelloExperimentalProtocol.docx

- CiotaCiaracaveFlakesandCores.xIsx

- CiotaCiaracaveExperimentalFlakes.xIsx

- CiotaCiaracaveExperimentalcores.xlsx

- DatabaseTesiQPA.accdb

- PirroNordandMontepoggioloExperimentalFlakes.xlsx

- PirroNordandMontepoggioloExperimentalcores.xlsx

- PirroNordFlakesandCores.xlsx

- RiparoTaglienteExperimentalFlakes.xIsx

- RiparoTaglienteExperimentalcores.xlsx

- RiparoTaglienteFlakesandCores.xlsx 